\title{
Apprenticeship non-completion in Germany: a money matter?
}

\author{
Caroline Neuber-Pohl* ${ }^{*}$
}

\section{*Correspondence:} neuber-pohl@bibb.de Federal Institute for Vocational Education and Training, Robert-Schuman-Platz 3 53175 Bonn, Germany

\begin{abstract}
German establishments heavily rely on the apprenticeship system for skill supply. With one in four apprenticeship contracts ending before successful completion, it is in the interest of establishments and policy-makers to determine factors, which reduce non-completion. This paper investigates the role of apprenticeship wages and income prospects after completion for apprenticeship non-completion in Germany. For this purpose, this study identifies incidences of apprenticeship non-completion in a large sample of administrative data on employment biographies and estimates a piecewise exponential model of the non-completion hazard with shared frailties by occupations. The results suggest a robust and significant association with both apprenticeship wages and skilled worker wages. All else at means, apprenticeships which are paid 5\% more than the mean apprenticeship wage, on average have a 0.8 percentage points higher estimated survival rate. In turn, an apprenticeship expected to lead to a skilled job that is paid 5\% above average, has an estimated survival rate, which is 3.1 percentage points higher on average. These findings highlight the importance of income prospects for apprenticeship non-completion.
\end{abstract}

Keywords: Vocational education and training, Apprenticeship, Non-completion, Attrition, Wages

\section{Introduction}

Not every apprenticeship ${ }^{1}$ in Germany ends successfully; i.e., with obtaining of the nationally standardized diploma. Uhly (2020b) calculates that currently one in four apprenticeship contracts is terminated before its end date. Moreover, the number of early contract terminations ${ }^{2}$ has increased almost continuously over the past decade.

Although apprenticeship non-completion can also be a good consequence of the occupational orientation of young apprentices (Rohrbach-Schmidt and Uhly 2015), the rise in early contract termination rates raises concerns, because apprenticeship non-completion

\footnotetext{
${ }^{1}$ For simplicity, the term apprenticeship refers to programs in the German dual system of vocational education and training in the following.

${ }^{2}$ In Germany, apprentices and training firms usually form a contract for the course of the apprenticeship. Despite some overlap, non-completion and early termination are distinct concepts; early contract terminations are not always incidences of non-completion, for instance when the apprentice changes occupations, thus contracts, while staying in the establishment. In turn, the number of early contract terminations does not capture incidences of non-completion after passage of the contract end date. For more information see Uhly (2015).
}

(c) The Author(s) 2021. This article is licensed under a Creative Commons Attribution 4.0 International License, which permits use, sharing, adaptation, distribution and reproduction in any medium or format, as long as you give appropriate credit to the original author(s) and the source, provide a link to the Creative Commons licence, and indicate if changes were made. The images or other third party material in this article are included in the article's Creative Commons licence, unless indicated otherwise in a credit line to the material. If material is not included in the article's Creative Commons licence and your intended use is not permitted by statutory regulation or exceeds the permitted use, you will need to obtain permission directly from the copyright holder. To view a copy of this licence, visit http://creativeco mmons.org/licenses/by/4.0/.

\section{SpringerOpen}


may be costly for training firms and apprentices alike. Especially in light of increasing shortages of skilled labor and apprentices, reducing apprenticeship non-completion has been a common goal for policy-makers, employers, and unions (cf. Rohrbach-Schmidt and Uhly 2015). ${ }^{3}$

Recently, apprenticeship non-completion has received public attention when German policy-makers called for a minimum wage for apprentices. The primary goal of such a policy is to increase the attractiveness of occupations that have problems filling their vacancies. Furthermore, increasing low apprenticeship wages is suggested to decrease apprenticeship non-completion, as for instance the Vice President of the German Trade Union Confederation $\left(\mathrm{DGB}^{4}\right)$ argued in a speech in favor of the minimum apprenticeship wage (DGB 2019). This paper investigates the actual existence of a correlation between the apprenticeship wage and non-completion. In addition, this study analyzes the relevance of wage prospects after completion.

In recent years, a strand of literature evolved studying the determinants of apprenticeship non-completion in Germany (Kotte 2019a, b; Wydra-Somaggio 2017; Bessey and Backes-Gellner 2015; Rohrbach-Schmidt and Uhly 2015; Kropp et al. 2014). However, with the exception of the study of Kropp et al. (2014), research has not focused on pecuniary factors as determinants of non-completion. In their study, Kropp et al. (2014) find a significantly negative association of apprenticeship wages and the share of early contract terminations, however only for a regionally restricted sample of apprenticeships in industrial and trade occupations in the Halle-Dessau area.

Although so far, no evidence exists for the relevance of wage prospects for apprenticeship non-completion in Germany, related studies provide some insight. Mangan and Trendle $(2017,2008)$ find a negative association of non-completion and wages after completion in Australia. For Switzerland, some studies also show that wage expectations influence turnover in related education and labor market situations. Rinawi and BackesGellner (2020) find evidence for significantly higher rates of apprentice retention after completion for establishments, which use performance pay schemes in Switzerland. According to the authors, performance pay increases the costs of leaving the firm for high-productivity workers such that the retention rate is higher. Similarly, Schweri and Hartog (2017) present evidence that Swiss nursing apprentices who expect higher wage premia from attending nursing college have a higher probability to continue their education at the tertiary level after completing their apprenticeship. In contrast, Bessey and Backes-Gellner (2015) do not find any significant evidence for an association of income prospects and the continuation of education after an early termination of the apprenticeship contract.

Furthermore, apprenticeship non-completion partly relates to dropping out of higher education at the tertiary level. The studies by Stinebrickner and Stinebrickner (2012, $2014)$ and Arcidiacono et al. $(2012,2020)$ find that wage expectations play an important role for dropping out and switching the major at US colleges. More specifically, the studies show that students learn about their own performance in the course of their studies,

\footnotetext{
3 Also see, for example, the goals of the Alliance for Apprenticeship and Further Education (In German: Allianz für Aus- und Weiterbildung) 2015-2018; see https://www.bmas.de/SharedDocs/Downloads/DE/allianz-aus-weiterbildung2019-21.pdf.

${ }^{4}$ In German: Deutscher Gewerkschaftsbund.
} 
update their earnings expectations in consequence and continue their study only if it is still profitable.

The applicability of this previous evidence to apprenticeship non-completion in Germany, however, is not trivial. For one, in contrast to apprenticeship retention after completion and the transitioning to or continuation of a college education, apprenticeship non-completion is not only characterized by wage prospects but also the immediate pay-off from the apprenticeship wage. Moreover, non-completion of apprentices is likely to differ from that of college students, because they are mostly younger (cf. Bonin et al. 2016). Also, apprentices are employees of an establishment. Hence, there is a closer link between the selection of apprentices into apprenticeships and non-completion to skill demands at the labor market. Apprentices also observe their job suitability directly on the job, thereby granting them a different information access to update their earnings expectations.

This paper adds to the existing literature by analyzing the role of pecuniary benefits in this special case of apprenticeship non-completion in Germany and provides first evidence that both the apprenticeship wage and wages after completion are negatively associated with non-completion.

\section{Apprenticeship non-completion in Germany}

Despite an increase in the enrollment in academic programs, apprenticeships in the German system of dual vocational education and training (VET) are still the most common way to receive a vocational education in Germany. About $54.5 \%$ of the population starts an apprenticeship at some point in their life (Uhly 2020a).

An apprenticeship combines on-the-job training with school-based courses on both general and occupation-specific skills. While the municipality provides the latter in local trade schools (Berufsschulen), apprenticeship seekers apply directly to a training establishment for the former. When recruited, apprentices sign an apprenticeship contract, which outlines, among other things, the occupation title, the curriculum, working hours, and the apprenticeship wage and its progression over the course of the apprenticeship.

Depending on the occupation-specific curriculum and the applicant's level of education, an apprenticeship usually lasts between two and three and a half years. At the end, apprentices take part in a final exam organized by their profession's guild. Upon passing, apprentices receive a nationally standardized and recognized diploma, which completes their apprenticeship.

However, for the year 2018, Uhly (2020b) calculates that $26.5 \%$ of the apprenticeship contracts were terminated without successful completion. Since 2008, this share has been increasing and since 2016 it exceeds the usual range of fluctuation between $20 \%$ and $25 \%$ (see Fig. 1).

There are several reasons for apprenticeship non-completion. The apprentice can quit or the establishment can terminate the contract (cf. Beicht and Walden 2013, p. 2). Also, Schöngen (2003) estimates that $12 \%$ of early contract terminations are a result of establishment relocation or shutdown.

Furthermore, non-completion does not necessarily have to raise concerns, as it also reflects the natural act of rematching between training establishments and apprentices to achieve more suitable matches (cf. Rohrbach-Schmidt and Uhly 2015). Notably, 


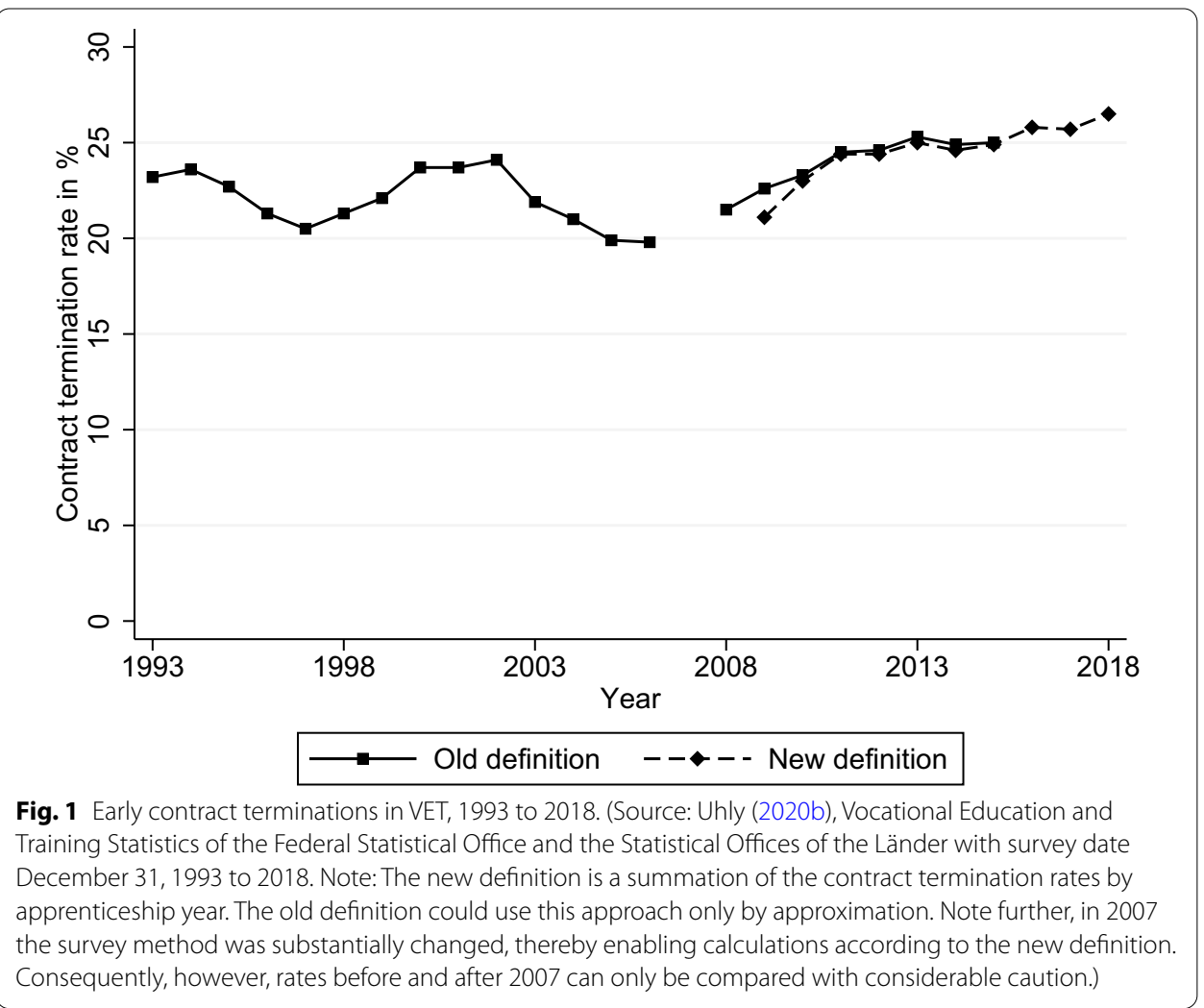

Wydra-Somaggio (2017) suggests that $72 \%$ of non-completers start another apprenticeship thereafter.

Nevertheless, non-completion may also adversely affect establishments and apprentices. For establishments, apprenticeship non-completion can be problematic for three reasons: First, non-completion leads to the loss of human capital, which especially harms establishments, which train to secure their skill supply. Note here, early contract termination varies largely across occupations. It is as high as $51.2 \%$ for hairdressers and, in contrast, as low as 5.5\% for administrative clerks (Uhly 2020b). Moreover, RohrbachSchmidt and Uhly (2015) estimate that the occupation explains $14.5 \%$ of the variance in early apprenticeship contract termination. Furthermore, the authors find that occupations with higher numbers of apprenticeship vacancies have a significantly higher rate of early contract termination. Hence, non-completion may especially pose a threat to the skill supply in less attractive occupations.

Second, most German training establishments follow an investment motive meaning that apprenticeships incur substantial costs in the beginning and recoup them only later with tenure of the apprentice (cf. Schönfeld et al. 2016; Mühlemann and Wolter 2014; Mohrenweiser and Backes-Gellner 2010). For these establishments, non-completion equals high sunk costs. Wenzelmann and Lemmermann (2012) estimate a total of irrevocable net costs of 580 million Euros ${ }^{5}$ from apprenticeship non-completion in the year 2007.

\footnotetext{
${ }^{5}$ This number corresponded to approximately 795 million US dollar in 2007 (see time series BBEX3.A.USD.EUR. BB.AC.A04 of the Deutsche Bundesbank, bundesbank.de).
} 
Third, repeated experience of non-completion may potentially lower the establishments' participation in apprentice training in the long run. According to a study by Mohr et al. (2015), 18\% of the surveyed establishments mentioned non-completion as a reason for reducing their apprenticeship offers.

For apprentices, on the other hand, non-completion jeopardizes future career paths as it could carry the stigma of an unproductive worker; i.e., a lemon (Akerlof 1970; Katz and Ziderman 1990), which other establishments do not want to train nor employ. If so, this limits the apprentice's chances of finding a high quality alternative within the apprenticeship system. Furthermore, non-completion may bear the risk of entirely dropping out of the vocational system, which, according to Wolter and Ryan (2011), increases the risk of low pay and precarious employment in the future.

\section{Theoretical considerations}

The cost-benefit framework of turnover behavior provides the theoretical backdrop for the importance of pecuniary pay-offs from apprenticeships. It assumes that non-completion is a rational decision that reflects a cost-benefit analysis of the apprentice and the training establishment alike. For both, committing to an apprenticeship, similar to any other investment into education and training, is only worthwhile when its net present value is positive (cf. Becker 1962). Hence, they will end the apprenticeship when its benefits fall short of its costs. In line with Mortensen's (1988) considerations regarding turnover decisions in the labor market, the possibility of quitting is a form of insurance against unfavorable developments in profitability of the current choice.

Mangan and Trendle (2008) express the importance of pecuniary benefits for apprenticeship non-completion in a utility model. According to this model, the utility $U_{i j t}$ of an apprenticeship position $j$ at time $t$ for apprentice $i$ essentially is a composite of two separate utilities, such that

$$
U_{i j t}=U\left(u_{i j t}^{(1)}, u_{i j t}^{(2)}\right)
$$

where the function $U(\cdot, \cdot)$ is common to all apprenticeships and determines the relative weight of the two components. The first component states that

$$
u_{i j t}^{(1)}=u^{(1)}\left(W_{i j t}, X_{i j t}\right)
$$

where $W_{i j t}$ expresses the pecuniary pay-offs and $X_{i j t}$ the non-pecuniary benefits from being in an apprenticeship at time $t$ relative to those from the available outside options $j$. Hence, $u_{i j t}^{(1)}$ captures the instantaneous net benefits of the apprenticeship.

Although apprentices in Germany do not pay tuition, following apprenticeship $j$ also bears costs, which lower $U_{i j t}$. One of these costs is the effort $e_{i j t}$ that is required to complete apprenticeship $j . e_{i j t}$ is increasing in the occupation's task complexity $c_{j}$, however decreasing in the apprentice's productivity $p$, which itself is a function of ability $a_{i}$, job suitability $\eta_{i j}$, and accumulated specific human capital $\kappa_{i t}$. The first component of the utility can, thus, be written as

$$
u_{i j t}^{(1)}=u^{(1)}\left(W_{i j t}, X_{i j t}, \frac{c_{j}}{p\left(a_{i}, \eta_{i j}, \kappa_{i t}\right)}\right) .
$$


Apprenticeship wages are known at the beginning of the apprenticeship and defined by the apprenticeship contract. They, however, may affect non-completion because many aspects of $u_{i j t}^{(1)}$ are a priori unknown. Apprentices are mostly young and new to the labor market. In fact, in 2018 apprentices below the age of 24 signed about $88 \%$ of new contracts (Uhly 2020a, p. 165). Hirschi (2011) finds that consolidating career choices, although highly dependent on individual characteristics, is a function of time. In addition, Stamm (2012) and Bohlinger (2002) point out that career orientation in school is often deficient. As a result, apprentices are often insufficiently informed about what to expect of an apprenticeship. In consequence, they reevaluate the appropriateness of the apprenticeship wage on the job. Therefore, even though apprenticeship wages are known from the start, there is an association of the apprenticeship wage and non-completion.

One unknown aspects, which is weighed against the apprenticeship wage, is job suitability $\eta$, which can only be learned over time with observation of on-the-job performance (cf. Jovanovic 1979). Discovering low job suitability increases the costs of staying and, thus, the probability of non-completion if wages cannot offset the costs. Furthermore, the required effort is a priori unknown. Gambin and Hogarth (2016) argue that apprentices discover dislike of certain job tasks only on the job; they reevaluate the appropriateness of apprenticeship wages, which, in turn, affects work morale and ultimately non-completion behavior. Moreover, insufficient information also concern nonpecuniary benefits as, for example, working conditions, career chances and the quality of the apprenticeship program in the training establishment. Analyzing a survey of 2000 German establishments, Christ (2013) provides some evidence for the latter by showing that non-completion occurs less often in training establishments who see apprenticeships as an investment into their future labor supply.

Adding the costs of effort has two other implications for the importance of the apprenticeship wage. First, changing jobs and occupations comes at the cost of losing jobspecific skills $\kappa$ (cf. Garloff and Kuckulenz 2006; Becker 1962). As $\kappa$ is increasing in $t$, non-completion becomes less likely over time regardless of the apprenticeship wage or other benefits. This may partly explain the decreasing rates of apprenticeship non-completion over tenure (cf. Uhly 2020b). ${ }^{6}$ In contrast, apprenticeship wages are increasing with each completed apprenticeship year to reflect this gain in skills and increased job requirements. Therefore, not accounting for tenure may underestimate the association of the apprenticeship wage and non-completion.

Second, the relationship between pecuniary benefits of an apprenticeship and noncompletion is biased by the selection on ability. Assuming apprentices are aware of their own ability at the start of the apprenticeship, high ability apprentices can select into comparably high-cost apprenticeships, which are more complex and take more effort. Because of their lower cost of staying in the apprenticeship, high-ability apprentices also have lower probabilities of non-completion. In fact, for Swiss apprenticeships, Schmid and Stalder (2012) document that the rate of early contract terminations is actually decreasing in task complexity. Assuming that wages partly compensate task complexity, indicates that quitting to upgrade to more complex and more profitable apprenticeships

${ }^{6}$ However, Uhly (2015, pp. 12) points out that also less strict employment protection during the trial period may contribute to the especially high rates in the first four months of an apprenticeship. 
is a strong motive for non-completion and, thus, that pecuniary benefits matter. At the same time, the observation of Schmid and Stalder (2012) corresponds to less able apprentices selecting into less complex apprenticeships, thereby increasing non-completion. Hence, not controlling for selection on ability would lead to an overestimation of the association of non-completion and the apprenticeship wage.

Furthermore, the importance of pecuniary benefits for non-completion may differ according to ability. On the one hand, apprentices who graduated from lower tracks of high school ${ }^{7}$ have lower possibilities of finding an apprenticeship in their dream occupation (Rohrbach-Schmidt and Uhly 2015; Protsch 2014). Hence, they may quit more often to search for better and more profitable apprenticeships; the association between pecuniary benefits and non-completion would then be stronger.

On the other hand, apprentices, who hold a high school diploma from the academic track and also could have decided to go to university, may more often strategically use an apprenticeship to continue to the academic system. In fact, Scheller et al. (2013) document that $22 \%$ of university entrants in 2011 already had obtained a VET degree. Bellmann and Stephani (2012), for example, show that a so-called double qualification, referring to the holding of a VET and additionally an academic diploma, positively affects several dimensions of job satisfaction. For Swiss graduates, Tuor and BackesGellner (2010) show that the combination of VET and academic education is associated with higher earnings after completion than both a purely VET or a purely academic education.

In addition, apprentices from the academic track may also more often end their apprenticeship before completion to transfer to university. Admission to popular university programs in Germany partly depends on waiting time; i.e., time passed after high school graduation. Hence, it is common practice in some fields of study to start an apprenticeship while waiting for university admission. Note however, that early contract termination rates are still lowest for apprentices from the academic track (15.6\% in 2018 cf. Uhly 2020b). Furthermore, Schnitzler (2020) finds that only about a third of apprentices from the academic track who terminated their apprenticeship contract early continued to study at a university. ${ }^{8}$

Whether or not the apprenticeship is completed, for graduates who actually strive for future benefits of jobs at the academic level the benefits of the apprenticeship may be of less or even no importance. Hence, the association of pecuniary benefits of an apprenticeship and the non-completion hazard may be lower for apprentices from the academic track on average.

The second component $u_{i j t}^{(2)}$ denotes the utility from $W_{i j t}$ given $E\left(W_{i j t}^{(m)}\right)$, such that

$$
u_{i j t}^{(2)}=u^{(2)}\left(W_{i j t} \mid E\left(W_{i j t}^{(m)}\right)\right) \text {, }
$$

\footnotetext{
${ }^{7}$ The German high school system is split into three tracks: The lowest track (Hauptschule), an intermediate track (Realschule), and an academic track (Gymnasium). The latter directly leads to obtaining the Abitur, which enables graduates to attend university.

${ }^{8}$ Half of them started another apprenticeship (Schnitzler 2020).
} 
where $W_{i j t}^{(m)}$ is the average wage after completion of an apprenticeship; i.e., that of skilled workers $(\mathrm{m})^{9}$ (Mangan and Trendle 2008). The second component, thus, captures the apprentice's trade-off between current and future pecuniary benefits from completion. Notably, this trade-off is a vital concept of apprenticeship financing, where apprentices willingly accept a wage below their productivity as unskilled workers in exchange for apprenticeship training and expected larger profits in the future as skilled workers (cf. Stevens 1994). If wage prospects, however, fall short, the apprenticeship becomes less attractive and, thus, is prone to non-completion.

Unlike apprenticeship wages, which are predetermined by contract, wages after completion are unknown to the apprentice and wage expectations evolve during the apprenticeship. On the one hand, this happens due to misjudgments of earning possibilities. Using an experimental design, Wiswall and Zafar (2015a, b), demonstrate how US college students severely misjudge earning risks of college majors. In addition, expected wages after completion are a function of job suitability. Low job suitability decreases productivity, which effects wages in the occupation as a skilled worker (cf. Jovanovic 1979). ${ }^{10}$ Note here that skilled workers with a completed apprenticeship in Germany are relatively immobile across occupations. Although Kropp and Schmillen (2012) estimate that one third of all individuals with completed apprenticeships worked in different occupations in 2008 as compared to 2005, they find that changes mostly occur in related occupations. Commitment to an apprenticeship, thus, strongly predicts future career paths and income streams. Because of learning about wage prospects, wages after completion are expected to be an important determinant for non-completion.

Finally, a third component has to be added to the utility function.

$$
u_{i j t}^{(3)}=u^{(3)}\left(W_{i j t} \mid U_{i-j t}\right),
$$

states that the apprentice forgoes pecuniary profits of the available alternatives $(-j)$ within the apprenticeship system, other education tracks, or low skilled employment opportunities in the labor market. Thus, a plethora of high-utility outside options exerts upward pressure on the current and future pecuniary pay-offs of an apprenticeship.

A few studies outline the importance of outside options for apprenticeship noncompletion. Rohrbach-Schmidt and Uhly (2015) find that a comparably large share of vacancies per apprenticeship seekers in German regions is significantly positively associated with non-completion. Similarly, Mühlemann et al. (2013) demonstrate how local monopsony power of training establishments significantly influences non-completion in Switzerland. More specifically, the authors estimate an increase in non-completion by $35 \%$ from a one standard deviation increase in the number of establishments. Hence, an abundance of apprenticeship offers facilitates transitions within the apprenticeship system and fosters non-completion.

Furthermore, Jaik and Wolter (2019) find evidence for Switzerland that an excess supply of apprenticeships at the beginning of an apprenticeship significantly increases the

\footnotetext{
${ }^{9}$ In the following, (m) denotes the skilled workforce with a completed apprenticeship; (l) refers to unskilled workers without completed apprenticeship, and (h) to high skilled workers with a tertiary degree.

10 This relates to the literature of young labor market entrants. By introducing the concept of job shopping, Topel and Ward (1992) have shown that turnover is a vital part of gathering information for young labor market participants.
} 
probability of an early contract termination in the first two years of that apprenticeship. Thus, the availability of apprenticeships is also correlated with match quality; if more apprentices apply per apprenticeship, establishments can select better candidates with a lower probability of non-completion.

Given that pecuniary benefits also partly increase with labor scarcity, a relatively high availability of apprenticeships, thus, corresponds to higher wages and higher non-completion. Hence, not controlling for the availability and profitability of outside options would underestimate the association of pecuniary benefits and non-completion.

\section{Data and data preparation}

The following analysis uses the Sample of Integrated Employment Biographies (SIAB) by the Institute of Employment Research $\left(\mathrm{IAB} ;{ }^{11}\right.$ for a detailed documentation see Antoni et al. 2016). SIAB is a 2\% sample of all individuals in the registry of the Federal Employment Agency (BA ${ }^{12}$ ) between 1975 and 2014. The registry combines process data of mandatory establishment reports on their employees who are subject to social security contributions, social benefit histories, participation in BA labor market measures, registered job seeking, and obtained unemployment benefits. SIAB provides all of this information as spell data in days and, thus, provides labor market biographies for the sample individuals. The data do not document times of self-employment, unregistered job seeking, or university enrollment, consequently creating biographical gaps. However, since April 1999, SIAB contains periods of marginal employment.

SIAB distinguishes regular employment from apprenticeships ${ }^{13}$ and this analysis uses entries of solely firm-sponsored apprenticeships, which started between 2000 and 2013.

In contrast to other survey data, the large sample size of SIAB allows for the adequate control of heterogeneity of wages and non-completion by year, industry, and occupation. Furthermore, as SIAB is based on administrative records, it eliminates some common sources of bias in survey data. For one, SIAB is not subject to attrition bias, which would lead to an underrepresentation of non-completion late in the apprenticeship. Also, Uhly (2015, p. 49) point out, that survey respondents quite often do not report non-completion especially when the respective apprenticeship period was short.

Nevertheless, identification of apprenticeship non-completion is not trivial as discussed in the following.

\section{Identification of apprenticeship non-completion}

SIAB does not provide direct information on successful completion of apprenticeships or early contract termination. However, the information is indirectly accessible, namely by observing a change in the highest vocational education level at the end of an apprenticeship period. This identification strategy leads to an estimation of apprenticeship noncompletion of $38.9 \%$, which is very large.

\footnotetext{
${ }^{11}$ In German: Insitut für Arbeitsmarkt- und Berufsforschung.

12 In German: Bundesagentur für Arbeit.

13 Note that apprenticeships in SIAB refer to all apprentices, who train at establishments and receive an apprenticeship wage. The number, thus, goes beyond the apprenticeships, which are regulated in the VET and Craft Trade Act (Berufsbildungsgesetz, BBiG and Handwerksordnung, HWO), especially as SIAB also includes apprenticeships in medical care professions, which formally belong to the school-based VET sector and, nevertheless, are contained in this analysis.
} 
Note that this rate excludes apprentices who already started with a previously completed apprenticeship, as it is impossible to observe a change in their education. Furthermore, the rate already corrects for breaks in the apprenticeship, when apprentices continue their apprenticeship in the same training establishment, for instance after parental leave, longer illness, or internships. In addition, changes of the occupation during the apprenticeship in the same training establishment are not counted as non-completion, because it is generally possible to decide on the actual training occupation later on. Moreover, establishments probably perceive occupational changes to a lesser extent as a loss in investments.

Despite this, the rate is overestimated because of two important identification problems. First, as information on education is voluntary in SIAB, they are often missing or contain inconsistent entries; i.e., a downgrade in the reported level of education (cf. Fitzenberger et al. 2005). Second, firms do not always report educational attainment as changes in degree often coincide with a change of the employer. Furthermore, it is possible to take the final exam after the end of the apprenticeship contract and even after leaving the training establishment.

To deal with these drawbacks, an elaborate verification procedure is applied. First, the information of education is cleaned. In cases of inconsistencies, the education level is verified following the procedure proposed by Fitzenberger et al. (2005, third variant of the imputation rules). In addition, reports on successful completion or quits from the unemployment registries is used to verify the education level. Similarly, changes in the education variable within 183 days of the end of the apprenticeship period are assumed to indicate its successful completion, because this time span is arguably too short to obtain another VET certificate elsewhere. Overall, cleaning the information on education lowers apprenticeship non-completion in the sample to $28.8 \%{ }^{14}$

Second, the actual timing of the end of apprenticeship periods is cleaned to rule out late reports of successful completion. Increases in job requirement levels ${ }^{15}$ during the apprenticeship are assumed to indicate an unregistered completion of an apprenticeship. Similarly, sudden increases in the daily wage are interpreted as an end of an apprenticeship. Accordingly, an apprenticeship is assumed to have come to successful completion when the wage increases by at least two thirds of its sample mean, while accounting for differences in education premia by the two-digit occupations of the Classification of Occupations $\left(\mathrm{KldB}^{16}\right)$ 2010, 10 industrial sectors, small, medium and large establishments and East and West Germany. The cleaning of the apprenticeship's end date leads to a lowering of non-completion to $26.9 \% .^{17}$

Third, the sample is limited to regular apprenticeships, by reducing it to full-time and first-time apprenticeships. The sample is further limited to apprentices aged 16 to 25

\footnotetext{
14 The cleaning of inconsistencies, the use of information from unemployment registries, and the accounting for late changes in the education variable reduce the rate of non-completion by 3.2, 1.6, and 5.3 percentage points, respectively.

15 The job requirement level here refers to the fifth digit of the Classification of Occupations (KldB) 2010. It indicates whether the job position is appropriate for a person without a formal vocational qualification, a VET qualification, a specialized VET qualification, or an academic qualification.

16 in German: Klassifikation der Berufe.

17 In addition to the previous reductions, accounting for wage increases and increases of the job requirement level reduce the rate of non-completion by 1.8 and 0.1 percentage points, respectively.
} 
at the start of the apprenticeship. ${ }^{18}$ Notably, this restriction excludes about $21 \%$ of the original sample and lowers non-completion further by 2.0 percentage points. ${ }^{19}$

Finally, the analysis time is censored after 1000 days. Thereafter, the incidence of noncompletion rises again in correspondence with the timing of final exams. Hence, by censoring before 1,000 days, this analysis largely excludes repeatedly failed exams and focuses on non-completion decisions during the apprenticeship. This restriction lowers non-completion by 4.0 percentage points.

In the end, the sample consists of information of 94,223 apprenticeships of which 19,697 end in non-completion. This yields a rate of non-completion of $20.9 \%$ for solely firm-sponsored apprenticeship, which started between 2000 and 2013. Notably, this number is smaller than Uhly's (2020b) calculation of the contract termination rate of $26.5 \%$. This difference, however, is reasonable given the exclusion of occupation changes within establishments and the restriction to younger first-time apprentices, who have a lower non-completion rate (also see Kropp et al. 2014, pp. 19). On the other hand, the rate is much higher than the estimation of $12 \%$ apprenticeship non-completion based on the BIBB Transition survey ${ }^{20}$ 2011. Uhly (2015, p. 49), however, shows that the Transition Survey underestimates non-completion of very short apprenticeship periods.

Figure 2 portrays the smoothed Kaplan-Meier estimate of the hazard function of noncompletion. Note that the non-completion hazard peaks towards the usual end of the trial period of four months. ${ }^{21}$ Thereafter, it decreases in a step-wise manner over the observation window. The plateaus towards the end of the first and second year of the apprenticeship coincide with usual timing of mid-term exams.

\section{Model variables}

The approximation of wages after completion $\left(W^{(m)}\right)$ uses the wage information in SIAB. ${ }^{22}$ Specifically, $\ln W^{(m)}$ denotes the natural logarithm of the mean daily wages of workers with a VET certificate distinguished by the two-digit level occupations of the KldB 2010, sex, industry, establishment size category, and location in East or West Germany (region) in the respective year ${ }^{23}$. Furthermore, $W^{(m)}$ only uses information on wages of full-time workers aged 30 to 64 to filter out starting wages and those of workers past retirement age.

The daily apprenticeship wage $W$ is directly available in SIAB. However, following Bessey and Backes-Gellner (2015), the relation between the individual apprenticeship wage and average wages of low skilled workers aged 18 to 30 in the same occupation and region $\left(W^{(l)}\right)$ is included. In this way, the variable captures the instantaneous pecuniary

\footnotetext{
${ }_{18}$ This age boundary covers about 88\% of all apprenticeship contracts (cf. Uhly 2020a, p. 165).

19 The age restriction and exclusion of part-time apprentices both additionally decrease the rate by 0.1 percentage points; the exclusion of repeaters decreases the rate by 1.9 percentage points.

20 In German: Übergangsstudie of the Federal Institute for Vocational Education and Training (BIBB)

21 The VET Act (BBiG) of 2005 mandates a trial period of minimum one and maximum four months, where the latter is commonly applicable. Before 2005, however, trial periods were shorter on average.

22 Wages above the ceiling for social security contributions are imputed following the approach of Gartner (2005). Multiple imputations approximate missing values.

23 To ensure sufficient observations for the calculation in every group, means are calculated as a three-year rolling average over the current, past and future years. This method also applies to low skilled worker wages and the variables of average days of unemployment.
} 


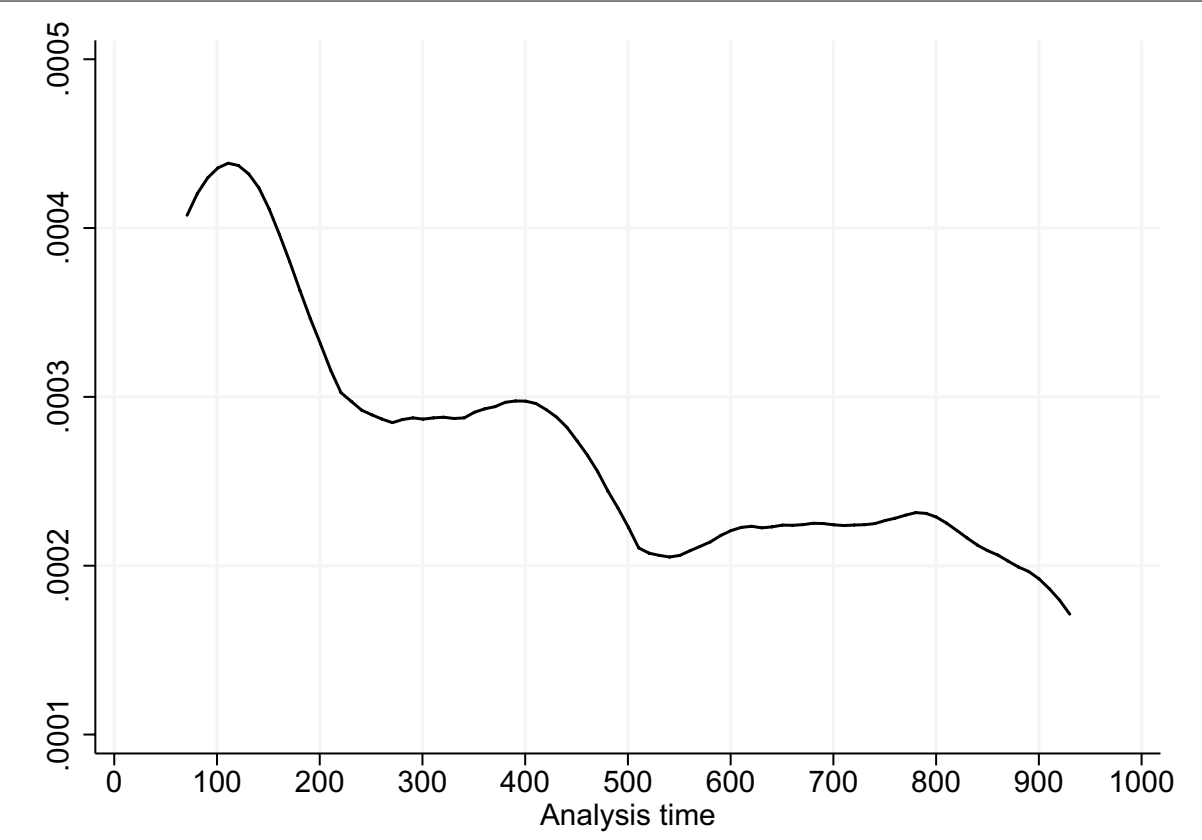

Fig. 2 Smoothed Kaplan-Meier estimate of the hazard function (Source: SIAB 2000-2013. Note: $N=94,223$ apprenticeships with 19,697 incidences of non-completion.)

benefit of the apprenticeship given its immediate outside option of low skilled work in the same occupation.

Further controls concern individual and training establishment characteristics. Furthermore, a number of labor market controls are included, which describe future career chances after apprenticeship completion and are likely correlated with $W / W^{(l)}$ and $\ln W^{(m)}$. Table 1 provides an overview and brief description of the variables.

\section{Sample descriptives}

Table 2 summarizes the sample means and standard deviations of the covariates for the entire sample and cases of non-completion. On average, apprentices in the sample earn 21.42 euro per day and have the prospects of earning 77.06 euro per day after apprenticeship completion. In contrast, apprentices not completing their apprenticeship only earn 17.03 euro per day and later have daily wages of 73.73 euro on average. ${ }^{24}$ Similarly, the relation with respect to low skilled worker wages is considerably lower for non-completion. On average, apprentices are paid 30\% of low skilled worker wages in cases of non-completion, while it is $33 \%$ in the entire sample. This descriptive evidence, however, also reflects the shorter tenure for cases of non-completion, which corresponds to a smaller progression of the yearly apprenticeship wage.

Further, note that there is a higher share of apprenticeships in service occupations and industries among the cases of non-completion. Moreover, the cases of non-completion comprise a higher share of graduates from the lowest track of high school and

${ }^{24}$ Between 2000 and 2013 the conversion rate fluctuated between 0.90 and 1.47 US dollar per one euro (see time series BBEX3.A.USD.EUR.BB.AC.A04 of the Deutsche Bundesbank, bundesbank.de). 
Table 1 Description of the model variables

\begin{tabular}{|c|c|}
\hline \multicolumn{2}{|l|}{ Wage variables } \\
\hline $\ln W^{(m)}$ & $\begin{array}{l}\text { Natural logarithm of the mean daily wages of full-time workers aged } 15 \text { to } 64 \text { with } \\
\text { a dual VET certificate distinguished by the two-digit level occupations of the KldB } \\
2010 \text {, sex, industry, establishment size category, location in East or West Germany } \\
\text { (region), and year }\end{array}$ \\
\hline$W / W^{(l)}$ & $\begin{array}{l}\text { Daily apprenticeship wage relative to mean daily wage of low skilled worker aged } 18 \\
\text { to } 30 \text { in the same two-digit level occupations of the KldB } 2010 \text { and region }\end{array}$ \\
\hline \multicolumn{2}{|l|}{ Individual-level controls } \\
\hline Time & $\begin{array}{l}\text { Dummy variables, } 1 \text { if tenure of apprenticeship is within the intervals }(0-60] \text {, } \\
(60-121],(121,212],(212-425],(425,547] \text { days }\end{array}$ \\
\hline Female & Dummy variable, 1 if female \\
\hline High school diploma & $\begin{array}{l}\text { Distinguishes between (1) none, (2) lowest track (Hauptschule), (3) intermediate track } \\
\text { (Realschule), and (4) academic track (Gymnasium) }\end{array}$ \\
\hline Start. age & Age at the beginning of the apprenticeship \\
\hline Start. age sqr. & Squared age at the beginning of the apprenticeship \\
\hline Start. year & Year of apprenticeship start \\
\hline Foreign & Dummy variable, 1 if foreign citizenship \\
\hline \multicolumn{2}{|c|}{ Establishment-level controls } \\
\hline Est. age & Establishment age in years \\
\hline Est. size & Distinguishes between 1 to 49,49 to 249 , and 250 and above employees \\
\hline Industry & Distinguishes 10 broad industrial sectors \\
\hline East Germany & Dummy variable, 1 if establishment location is in East Germany \\
\hline \multicolumn{2}{|l|}{ Labor market controls } \\
\hline SDR & $\begin{array}{l}\text { Supply to demand ratio as approximation for apprenticeship market tightness, cap- } \\
\text { tures the number of apprenticeship positions supplied by training firms in relation } \\
\text { to the number of apprenticeship seekers in the training occupation. Data source: } \\
\text { Survey of new apprenticeship contracts with survey date September } 30 \text { by the } \\
\text { Federal Institute for Vocational Education and Training }{ }^{a}\left(\mathrm{BIBB}^{b}\right)\end{array}$ \\
\hline MES & $\begin{array}{l}\text { Share of marginally employed individuals at the specific establishment in observa- } \\
\text { tion; approximation of career chances in establishment }\end{array}$ \\
\hline$u^{(l)} / u^{(m)}$ & $\begin{array}{l}\text { Mean unemployment days per year for }(I) \text { unskilled relative to }(\mathrm{m}) \text { skilled workers by } \\
\text { sex, occupation, region, and year }\end{array}$ \\
\hline$u^{(h)} / u^{(m)}$ & $\begin{array}{l}\text { Mean unemployment days per year for (h) high skilled relative to }(\mathrm{m}) \text { skilled workers } \\
\text { by sex, occupation, region, and year }\end{array}$ \\
\hline
\end{tabular}

${ }^{a}$ In German: BIBB-Erhebung Neu abgeschlossene Ausbildungsverträge zum 30.09.

${ }^{b}$ In German: Bundesinstitut für Berufsbildung

apprenticeships in small businesses. Considering the labor market controls, note that although the share of marginally employed individuals in the training establishment is higher on average in cases of non-completion, the difference in the supply-to-demandratio of apprenticeships (SDR) and unemployment risk variables $\left(u^{(l)} / u^{(m)}\right.$ and $\left.u^{(h)} / u^{(m)}\right)$ are considerably small.

\section{Method}

For this analysis a piecewise exponential (PWE) survival model estimates the non-completion hazard for apprenticeships. The PWE model assumes constant baseline hazards over specified time intervals. In contrast to the conventional exponential model, which assumes a constant baseline hazard of apprenticeship non-completion over the entire apprenticeship duration, the PWE model, therefore, allows for a more flexible functional form of the baseline hazard, which varies over the intervals.

The functional form of the PWE model is 
Table 2 Descriptive statistics by non-completion. Source: SIAB 2000-2013. $\mathrm{N}=641,921$ observations, $n=94,223$ apprenticeships, $f=19,697$ incidences of non-completion

\begin{tabular}{|c|c|c|c|c|}
\hline & \multicolumn{2}{|c|}{ Entire sample } & \multicolumn{2}{|c|}{$\begin{array}{l}\text { Incidences of non- } \\
\text { completion }\end{array}$} \\
\hline & Mean & SD & Mean & SD \\
\hline Daily apprenticeship wage $(W)$ & 21.64 & 8.23 & 17.03 & 8.34 \\
\hline $\begin{array}{l}\text { Apprenticeship wage in relation to low skilled workers wage } \\
\left(W / W^{(l)}\right)\end{array}$ & 0.34 & 0.13 & 0.30 & 0.14 \\
\hline Daily skilled worker wage $\left(W^{(m)}\right)$ & 81.70 & 22.15 & 73.73 & 20.30 \\
\hline Natural logarithm of daily skilled worker wage $\left(\ln W^{(m)}\right)$ & 4.36 & 0.29 & 4.26 & 0.29 \\
\hline Female & 0.44 & 0.50 & 0.48 & 0.50 \\
\hline Starting age & 18.32 & 1.90 & 18.60 & 1.95 \\
\hline Foreign & 0.05 & 0.22 & 0.07 & 0.26 \\
\hline \multicolumn{5}{|l|}{ High school diploma } \\
\hline None & 0.10 & 0.29 & 0.11 & 0.31 \\
\hline Lowest track & 0.28 & 0.45 & 0.39 & 0.49 \\
\hline Intermediate track & 0.42 & 0.49 & 0.36 & 0.48 \\
\hline Academic track & 0.19 & 0.39 & 0.14 & 0.34 \\
\hline Service occupation & 0.68 & 0.47 & 0.72 & 0.45 \\
\hline Service industry & 0.66 & 0.47 & 0.77 & 0.42 \\
\hline Establishment age & 19.65 & 11.57 & 17.00 & 11.46 \\
\hline East Germany & 0.18 & 0.38 & 0.21 & 0.41 \\
\hline \multicolumn{5}{|l|}{ Establishment size } \\
\hline 0-49 employees & 0.44 & 0.50 & 0.53 & 0.50 \\
\hline 50-249 employees & 0.27 & 0.45 & 0.27 & 0.44 \\
\hline 250+ employees & 0.29 & 0.46 & 0.19 & 0.40 \\
\hline Supply-to-demand-ratio of apprenticeships (SDR) & 0.99 & 0.06 & 1.00 & 0.07 \\
\hline Marginal employment share (MES) & 0.11 & 0.16 & 0.14 & 0.19 \\
\hline \multicolumn{5}{|l|}{ Average unemployment days of unskilled relative to } \\
\hline skilled workers $\left(u^{(l)} / u^{(m)}\right)$ & 1.94 & 0.80 & 1.95 & 0.79 \\
\hline \multicolumn{5}{|l|}{ Average unemployment days of high skilled relative to } \\
\hline skilled workers $\left(u^{(h)} / u^{(m)}\right)$ & 0.94 & 0.27 & 0.95 & 0.26 \\
\hline
\end{tabular}

$$
\log \left(\lambda_{s, i j t}\right)=\log \lambda_{s}+\alpha_{j}+x_{i j t}^{\prime} \beta
$$

where $\lambda_{s, i j t}$ denotes the hazard corresponding to individual $i$, in occupation $j$, and at tenure $t$ in time interval $s . x_{i j t}$ comprises a number of explanatory variables and $\beta$ is a vector of corresponding coefficients. The baseline hazard $\lambda_{s}$ is a constant over the specified interval of tenure.

For this analysis, the intervals defined by $s$ split the duration of the apprenticeship at $60,121,212,425$, and 547 days of tenure. Following the common approach (cf. RabeHesketh and Skrondal 2012), the interval cut-off days were chosen according to the non-parametric Kaplan-Meier estimate of the hazard function (see Fig. 2) and cut the hazard function into monotonous pieces with significantly different incidence rates ${ }^{25}$ (see Appendix: Table 5). Note that a similar estimation assuming the fully non-parametric functional form of the baseline hazard of the Cox survival model produces almost

25 The incidence rate is calculated as non-completion per person-time, which is the sum of duration in days in the specific time interval over all observed apprenticeships. 
identical results (see Appendix: Table 6). Therefore, the appropriateness of the chosen intervals is assumed. Furthermore, the estimation of a random intercept logit model support the significance and sign of the estimated associations.

The occupation-specific shared frailty, $\alpha_{j}$, is a gamma-distributed random component with mean one and variance $\theta$. It captures unobserved heterogeneity between the occupations and, thus, accounts for the high variation of apprenticeship non-completion across occupations. As wage profiles are very occupation-specific (cf. Bol and Weeden 2015), accounting for occupation-specific shared frailties allows disentangling the effect of wages from the occupation-specific effects.

In all of the tested model specifications, the variation between the shared frailties of the 35 occupational clusters, as measured by $\theta$, is significantly different from zero. The likelihood-ratio test compares the shared frailty against a fixed-effects model and supports the shared frailty model, meaning there is a significant heterogeneity between occupations.

Throughout, standard errors are adjusted for shared frailties in the 35 occupation clusters.

\section{Results and Discussion}

Table 3 presents the estimation results of three shared frailty PWE models. To observe the effect of adding control variables on the estimated hazard ratios of $W / W^{(l)}$ and $\ln W^{(m)}$, column 1,2 , and 3 contain the results from estimating a model without any control variables, a model considering a reduced set of only individual and establishment-level controls, and a model considering all controls including those characterizing the state of the labor market, respectively.

The table reports conditional hazard ratios (HR). This means that a value below (above) one indicates a negative (positive) association; i.e, a lower (higher) probability of non-completion in a given period. In turn, a hazard ratio of exactly one indicates that the respective variable is not associated with deviations from the average non-completion hazard.

\section{Wages and non-completion}

The results indicate for both $W / W^{(l)}$ and $\ln W^{(m)}$ that hazard ratios are significantly below one at a 5\% significance level (see Table 3). Given the results from estimating the full model considering all control variables, the hazard ratio corresponding to $W / W^{(l)}$ is 0.023 and that corresponding to $\ln W^{(m)}$ is 0.456 . As expected, this indicates that both a higher apprenticeship wage given a fixed low skilled worker wage and higher wages after completion are associated with a lower non-completion hazard.

This relationship is very robust throughout the three different model specifications. Especially, the hazard ratio of $W / W^{(l)}$ barely changes when including control variables. However, the hazard ratio of $\ln W^{(m)}$ declines when including apprentice and establishment-level controls (see Table 3, column 2). This suggests that not accounting for these characteristics understates the relationship between wages after completion and the non-completion hazard.

To illustrate, the size of the estimated hazard ratios for $W / W^{(l)}$ and $\ln W^{(m)}$, Fig. 3 shows the predicted survival functions corresponding to the estimation of model 3 in 
Table 3 Estimated hazard ratios for the piecewise exponential models of the apprenticeship noncompletion hazard

\begin{tabular}{|c|c|c|c|c|c|c|}
\hline & \multicolumn{2}{|c|}{ Without controls } & \multicolumn{2}{|c|}{$\begin{array}{l}\text { Additional } \\
\text { establishment and } \\
\text { apprentice level } \\
\text { controls } \\
\end{array}$} & \multicolumn{2}{|c|}{$\begin{array}{l}\text { Additional labour } \\
\text { market level controls }\end{array}$} \\
\hline & $H R$ & SE & $\mathrm{HR}$ & SE & $H R$ & SE \\
\hline$W / W^{(l)}$ & $0.019 * * *$ & $(0.001)$ & $0.022 * * *$ & $(0.002)$ & $0.023 * * *$ & $(0.002)$ \\
\hline $\ln W^{(m)}$ & $0.538 * * *$ & $(0.017)$ & $0.441 * * *$ & $(0.027)$ & $0.456 * * *$ & $(0.028)$ \\
\hline \multicolumn{7}{|l|}{ Time } \\
\hline \multicolumn{7}{|l|}{ (ref: (547-1000] days) } \\
\hline$(0-60]$ & $1.372 * * *$ & $(0.036)$ & $1.088 * *$ & $(0.029)$ & 0.985 & $(0.027)$ \\
\hline$(60-121]$ & $2.094 * * *$ & $(0.049)$ & $1.691 * * *$ & $(0.040)$ & $1.536 * * *$ & $(0.038)$ \\
\hline$(121-212]$ & $1.616 * * *$ & $(0.038)$ & $1.382 * * *$ & $(0.033)$ & $1.296 * * *$ & $(0.031)$ \\
\hline$(212-425]$ & $1.112 * * *$ & $(0.023)$ & 0.984 & $(0.029)$ & $0.933 * *$ & $(0.020)$ \\
\hline$(425-547]$ & $1.107 * * *$ & $(0.029)$ & 1.020 & $(0.027)$ & 0.983 & $(0.026)$ \\
\hline Female & & & $0.944 * *$ & $(0.021)$ & $0.864 * * *$ & $(0.023)$ \\
\hline \multicolumn{7}{|l|}{ High school diploma } \\
\hline \multicolumn{7}{|l|}{ (ref: lowest track) } \\
\hline None & & & $0.908 * * *$ & $(0.023)$ & $0.907 * * *$ & $(0.027)$ \\
\hline Intermediate track & & & $0.734 * * *$ & $(0.013)$ & $0.733 * * *$ & $(0.013)$ \\
\hline Academic track & & & $0.596 * * *$ & $(0.016)$ & $0.590 * * *$ & $(0.016)$ \\
\hline Start. age & & & $1.986 * * *$ & $(0.113)$ & $2.023 * * *$ & $(0.116)$ \\
\hline Start. age sqr. & & & $0.985 * * *$ & $(0.001)$ & $0.984 * * *$ & $(0.001)$ \\
\hline Start. year & & & $1.134 * * *$ & $(0.003)$ & $1.187 * * *$ & $(0.005)$ \\
\hline Foreign & & & $1.098 * *$ & $(0.031)$ & $1.106 * * *$ & $(0.031)$ \\
\hline \multicolumn{7}{|l|}{ Est. size } \\
\hline \multicolumn{7}{|l|}{ (ref: 1-49 employees) } \\
\hline $50-249$ & & & $0.846 * * *$ & $(0.018)$ & $0.859 * * *$ & $(0.005)$ \\
\hline $250+$ & & & $0.787 * * *$ & $(0.023)$ & $0.798 * * *$ & $(0.023)$ \\
\hline Est. age & & & $0.991 * * *$ & $(0.001)$ & $0.991 * * *$ & $(0.001)$ \\
\hline East Germany & & & $0.831 * * *$ & $(0.021)$ & 0.975 & $(0.030)$ \\
\hline \multicolumn{7}{|l|}{ Industry } \\
\hline \multicolumn{7}{|l|}{ (ref:Retail/wholesale/gastronomy) } \\
\hline Farming/fishing/forestry & & & 1.046 & $(0.080)$ & 1.039 & $(0.079)$ \\
\hline Earths/food/textiles & & & $0.724 * * *$ & $(0.028)$ & $0.719 * * *$ & $(0.028)$ \\
\hline Chemical/oil/metal & & & $0.586 * * *$ & $(0.023)$ & $0.581 * * *$ & $(0.023)$ \\
\hline Electronics/vehicles/misc. prod. & & & $0.627 * * *$ & $(0.031)$ & $0.617 * * *$ & $(0.030)$ \\
\hline Construction/water, energy supply & & & $0.817 * * *$ & $(0.032)$ & $0.815 * * *$ & $(0.032)$ \\
\hline Logistics/Postal/Banking & & & 0.964 & $(0.043)$ & 0.961 & $(0.043)$ \\
\hline Public/private services & & & $0.848 * * *$ & $(0.029)$ & $0.843 * * *$ & $(0.028)$ \\
\hline Health/education & & & $1.260 * * *$ & $(0.036)$ & $1.309 * * *$ & $(0.038)$ \\
\hline NGOs/culture/sports & & & $1.218 * * *$ & $(0.043)$ & $1.229 * * *$ & $(0.044)$ \\
\hline SDR & & & & & 0.728 & $(0.123)$ \\
\hline MES & & & & & $1.286 * * *$ & $(0.058)$ \\
\hline$u^{(l)} / u^{(m)}$ & & & & & $0.770 * * *$ & $(0.013)$ \\
\hline$u^{(h)} / u^{(m)}$ & & & & & $1.438 * * *$ & $(0.087)$ \\
\hline Constant & $0.012 * * *$ & $(0.002)$ & $0.000 * * *$ & $(0.000)$ & $0.000 * * *$ & $(0.000)$ \\
\hline$\theta$ & 0.216 & & 0.125 & & 0.115 & \\
\hline LR-test of $\theta$ & 3,610 & & 1,912 & & 1,509 & \\
\hline Log pseudolikelihood & $-174,247$ & & $-171,639$ & & $-171,485$ & \\
\hline Wald test & 5,534 & & 10,542 & & 10,821 & \\
\hline $\mathrm{AIC}$ & 348,513 & & 343,338 & & 343,038 & \\
\hline
\end{tabular}


Table 3 (continued)

$* * * \mathrm{p}<0.001, * * \mathrm{p}<0.01, * \mathrm{p}<0.05, \mathrm{~N}=641,921$ observations, $\mathrm{n}=94,223$ apprenticeships, $\mathrm{f}=19,697$ incidences of non-completion. The table reports conditional hazard ratios (HR) of the fixed component adjusted for shared frailties by 35 occupations and occupation cluster robust standard errors (SE). $W / W^{(l)}$ refers to the apprenticeship wage in relation to low skilled workers wage, $I n W^{(m)}$ to the natural logarithm of daily skilled worker wage, SDR to the supply-demand ratio of apprenticeships, MES to the marginal employment share of the establishment, $u$ to the number of unemployment days, and $\theta$ to the variance of the shared frailty

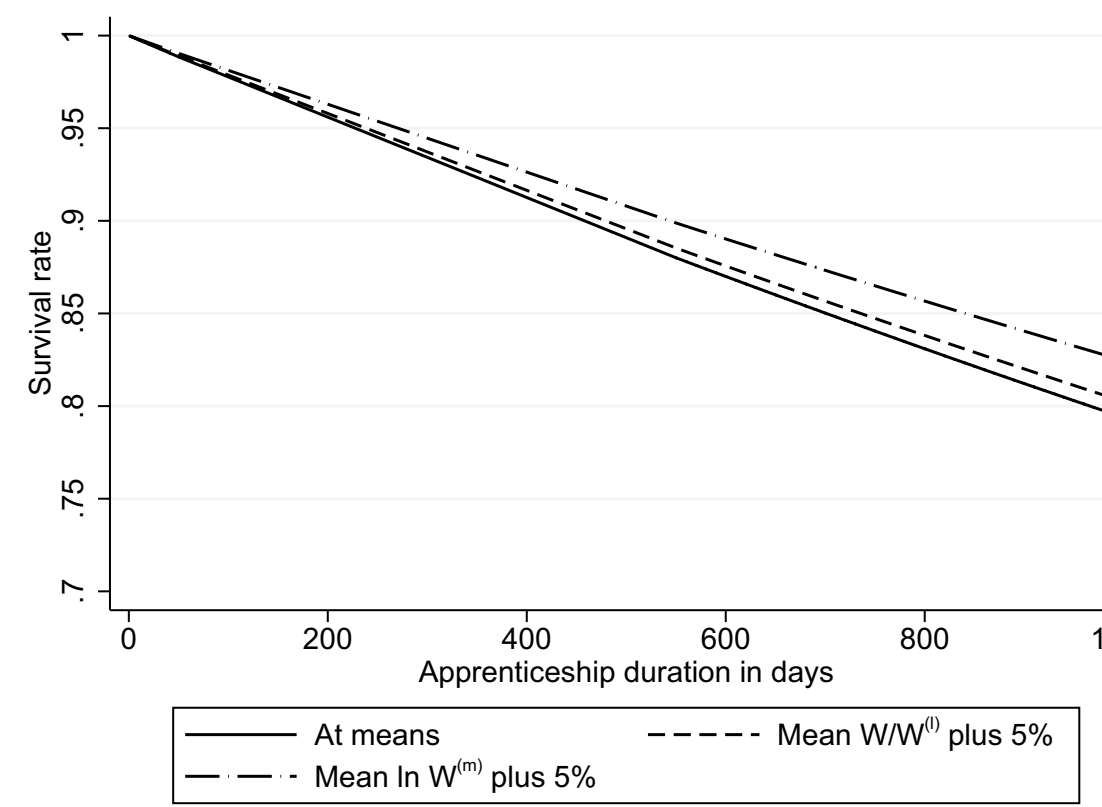

Fig. 3 Estimated survival function at different wage levels (Note: Estimation of the survival function of the model in Table 3, column 3 at means of all variables (at means), a 5\% above average apprenticeship wage relative to unskilled worker wage (mean $W / W^{(l)}$ plus $5 \%$ ), and a $5 \%$ above average natural logarithm of daily skilled worker wages (mean $/ n W^{(m)}$ plus 5\%); $N=94,223$ apprenticeships with 19,697 incidences of non-completion.)

Table 3 for different values of the two variables. The black solid line represents the survival function at the mean of the two variables and all other covariates at the respective time interval. The graph shows that the predicted survival rate at the end of the observation period of 1000 days is $79.4 \%$. This number includes apprenticeship completion and apprentices, who are still in their apprenticeship after censoring.

The dashed line shows the estimated survival function when $W / W^{(l)}$ is $5 \%$ above its average while $\ln W^{(m)}$ and all other covariates are at their mean. Here, the estimated survival rate is approximately $80.2 \%$. These results suggest that apprenticeships, which pay $5 \%$ above average, have on average a 0.8 percentage points higher survival within 1,000 days; i.e., a 0.8 percentage points lower non-completion rate.

The dash-dotted line represents the estimated survival function when $\ln W^{(m)}$ is $5 \%$ above its average, while all other variables are at their mean. In this case, the estimated survival rate is $82.5 \%$. This suggests that apprentices with the prospect of having a $5 \%$ above-average wage after completion have on average a 3.1 percentage points higher survival rate.

Hence, not only higher levels of apprenticeship wages are associated with a higher survival rate, but also higher levels of skilled worker wages are significantly associated 
with lower apprenticeship non-completion. This suggests that apprentices are not shortsighted in regards to non-completion, but consider their future pay-offs from continuing within the apprenticeship program.

However, these results cannot be interpreted as causal effects. For one, selection of apprentices into apprenticeships cannot be sufficiently controlled. Arguably, controlling for the occupation, industry, establishment size, region, and prior education of the apprentice partly captures selection, thereby reducing the selection bias of the estimated hazard ratios of $W / W^{(l)}$ and $\ln W^{(m)}$. Nevertheless, a different analytical design is needed to establish causality, which goes beyond the scope of this paper.

Another aspect, which limits a causal interpretation, is the omission of unobserved factors, which are likely correlated with apprenticeship wages, and wages after completion and at the same time influence non-completion. For example, establishments, which offer high apprenticeship wages may also be more likely to offer a well-structured, high quality apprenticeship program and general support. Hence, the association of the non-completion hazard and apprenticeship wages may partially reflect that apprentices stay for better learning opportunities rather than higher wages. Also, higher wages after completion may partially reflect better career prospects within the firm, which are an incentive to complete. Moreover, higher apprenticeship wages and wages after completion may correlate with a lower incidence of monotonous tasks or those that require physical strength (cf. Autor and Handel 2013). The investigation of the impact of these unobserved factors on the relationship between pecuniary benefits and apprenticeship non-completion has to be left for future research.

Besides these limitations, the results highlight the importance of apprenticeship wages and wages after completion for non-completion behavior. Although the results do not allow for a causal interpretation, they do indicate that not only instantaneous but also future pay-offs of an apprenticeship are an important factor when describing the non-completion hazard. Policies aiming at reducing the rate of apprenticeship noncompletion, therefore, should consider the (pecuniary and correlated non-pecuniary) benefits of an apprenticeship after completion instead of solely focusing on the regulating (instantaneous) apprenticeship wages.

\section{Robustness}

To check the robustness of the results, Appendix: Table 7 presents model estimations based on some alternative sample restrictions. First, the sample is restricted to apprentices aged 23 and younger (instead of 25 and younger) as suggested by Kotte (2019a, b); this does not alter the results by much (see Table 7, column 1 ).

Second, the contract termination rate started to continuously increase in 2006 (see Fig. 1). To check whether this increase is associated with changes in the role of the apprenticeship wage and wages after completion, the model is estimated using the split samples before and after 2006, respectively, in Table 7 (columns 2 and 3). The estimated hazard ratios for $W / W^{(l)}$ and $\ln W^{(m)}$ are largely unaffected by this sample split.

Third, the observation period covers two major recessions, the dot-com bubble, which lead to a decrease in GDP growth from 2000 to 2003 and the financial crisis of 2008 and 2009. In recessions, non-completion may increase due to mass layoffs. Furthermore, some studies find a small but significant decline of offered apprenticeships in economic 
downturns (measured in GDP growth, unemployment, or business cycle expectations; cf. Mühlemann et al. 2020; Lüthi and Wolter 2020; Bellmann et al. 2014; Mühlemann et al. 2009). With fewer outside option within the apprenticeship market, apprentices may more often choose to stay with their training company irrespective of the pecuniary benefits. In addition, apprentices that start during an economic downturn may be select. With higher numbers of applicants per apprenticeship, training establishments may decrease non-completion by screening a comparably larger pool of applicants for more suitable candidates (Rohrbach-Schmidt and Uhly 2015). Weßling et al. (2015) also show that in periods of higher unemployment, high school graduates more often turn to attending school-based education programs rather than starting an apprenticeship. If only apprentices without alternatives enter apprenticeships, non-completion should be lower.

To check whether the state of the economy influences the role of pecuniary benefits for non-completion, the sample is split into apprenticeships, which took place entirely in years of economic upturn (2004-2007 and after 2009) and those which had overlap with at least one year of economic downturns (2000-2003 and 2008-2009). The results in Appendix: Table 7 (columns 5 and 6) suggest that the estimated hazard ratios for the apprenticeship wage and wages after completion are largely unaffected by the sample split.

Finally, the dependence of the results on the censoring after 1,000 days is checked. Appendix: Table 8 presents results based on alternative censoring times at 914 days (2.5 years) and 731 days (2 years), respectively. Again, both estimations confirm the negative relationship of $W / W^{(l)}$ and $\ln W^{(m)}$ with the non-completion hazard.

\section{Further results}

Considering the other covariates, the results in Table 3 indicate a significantly higher non-completion hazard towards the end of the trial period (between 60 and 121 days of tenure) and right afterwards (between 121 and 212 days of tenure). Note that there is no sufficient evidence that the non-completion hazard within the first 60 days of the apprenticeship differs from that of day 547 to 1000 when accounting for further covariates. However, results in Appendix: Table 7 (column 3 and 4) suggest that the importance of this time span may have changed over the years. Only analyzing apprenticeships, which started before 2006, the results indicate a significantly lower hazard ratio in the first 60 days. In turn, it is significantly higher when only looking at apprenticeships, which started after 2006. A similar result appears for the period of 425 to 547 days. Moreover, the results of Appendix: Table 7 (column 5 and 6) suggest that the non-completion hazard is only decreasing with time in upturns. In downturns, it is always lower before day 547. This may indicate that apprentices try harder to hold on to their apprenticeship in downturns, such that unsuitable matches result in non-completion only later, for example, when the apprentices repeatedly fail exams.

Furthermore, the hazard ratios suggest that the non-completion hazard is lower for larger establishments. Similarly, it appears to decrease with higher levels of education; also, it is significantly lower for school leavers, who have not obtained a certificate from the lowest high school track as compared to those who did. The results further suggest that female apprentices have a lower hazard of non-completion. 
Concerning the additional labor market controls, the correlation of the non-completion hazard and SDR is not significant at the 5\% significance level. In turn, higher rates of marginal employment within the training establishment are associated with higher non-completion hazards. Similarly, higher unemployment risks of unskilled as compared to skilled workers $\left(u^{(l)} / u^{(m)}\right)$ is associated with lower non-completion hazards. Hence, it appears that lower prospects of regular employment positively correlate with non-completion.

In turn, the hazard ratio of the unemployment risk of high skilled workers as compared to skilled workers $\left(u^{(h)} / u^{(m)}\right)$ shows a significant positive association with noncompletion. This result probably indicates the importance of career prospects also in jobs, which require an academic education. Apprentices may continue in education to either obtain a specialized VET certificate (for example the master craftsman title) or a university degree after completing the initial apprenticeship. Note that here the high skilled workforce includes employees with either type of degree. Furthermore, this result can only be confirmed for apprenticeships in economic upturns, while the hazard ratio is not significant for apprenticeships in economic downturns. An explanation could be that in down-turns school-based programs increase in popularity with regards to entering the labor market (cf. Clark 2011). Weßling et al. (2015) provide evidence that lower track school graduates in Germany more often attend school-based VET programs when local unemployment is high. Similarly, school graduates from the academic track may more often attend university directly after high school instead of (first) opting for an apprenticeship when graduating in a recession.

\section{Accounting for interactions}

Arguably, the relationship of the apprenticeship wage and wage prospects and noncompletion depends on timing, apprentice's sex and level of education, and establishment size. Considering the timing of non-completion, the valuation of current and future wages may change while gathering information on the job. Furthermore, men and women may value monetary pay-offs differently. Lastly, the level of education and the size of the training establishment indicate outside options and future career chances. Therefore, it is reasonable to believe that the correlations of non-completion and apprenticeship wages and wages after completion depend on these characteristics. To investigate potential heterogeneity, a model is estimated, which includes interaction effects of $W / W^{(l)}$ and $\ln W^{(m)}$ with these variables.

Table 4 presents average marginal effects (AME) on the survival rate of a $1 \%$ increase in $W / W^{(l)}$ and $\ln W^{(m)}$, respectively, at different values of the interacting characteristics. Appendix: Table 9 presents the full results of this estimation. Note that the estimated average marginal effects of $W / W^{(l)}$ and $\ln W^{(m)}$ on the survival rate from the model in Table 3 (column 3) do not significantly differ when including interaction terms. ${ }^{26}$ However, they do reveal some differences according to the interacting characteristics.

\footnotetext{
${ }^{26}$ The estimated relative average marginal effects of a $1 \%$-increase in $W / W^{(l)}$ are 1.227 and 1.245 in the model including and excluding interaction terms, respectively. For $\ln W^{(m)}$ they are 3.700 and 3.425, respectively. In both cases, the estimates are not significantly different at the $5 \%$ significance level.
} 
Table 4 Average marginal effects on the survival rate in \% when accounting for interaction effects

\begin{tabular}{|c|c|c|c|c|c|c|}
\hline & \multicolumn{3}{|c|}{$W / W^{(l)}$} & \multicolumn{3}{|c|}{$\ln W^{(m)}$} \\
\hline & AME & SE & $95 \% \mathrm{Cl}$ & AME & SE & $95 \% \mathrm{Cl}$ \\
\hline \multicolumn{7}{|l|}{ Time } \\
\hline$(0-60]$ & 1.361 & $(0.071)$ & {$[1.222,1.500]$} & 7.072 & $(0.397)$ & {$[6.294,7.849]$} \\
\hline$(60-121]$ & 1.152 & (0.059) & {$[1.037,1.267]$} & 5.072 & $(0.366)$ & {$[4.354,5.789]$} \\
\hline$(121-212]$ & 1.086 & $(0.057)$ & {$[0.974,1.197]$} & 2.749 & $(0.378)$ & {$[2.008,3.490]$} \\
\hline$(212-425]$ & 1.737 & $(0.053)$ & {$[1.633,1.840]$} & 3.684 & $(0.341)$ & {$[3.017,4.352]$} \\
\hline$(425-547]$ & 1.184 & $(0.070)$ & {$[1.046,1.321]$} & 2.236 & $(0.425)$ & {$[1.402,3.070]$} \\
\hline$(547-1000]$ & 1.020 & $(0.044)$ & {$[0.934,1.107]$} & 2.259 & $(0.346)$ & {$[1.582,2.937]$} \\
\hline \multicolumn{7}{|l|}{ Sex } \\
\hline Male & 1.335 & $(0.039)$ & {$[1.259,1.412]$} & 3.994 & $(0.306)$ & {$[3.395,4.594]$} \\
\hline Female & 1.086 & $(0.033)$ & {$[1.021,1.152]$} & 3.316 & $(0.316)$ & {$[2.698,3.935]$} \\
\hline \multicolumn{7}{|l|}{ High school diploma } \\
\hline None & 1.337 & $(0.068)$ & {$[1.203,1.472]$} & 3.590 & $(0.387)$ & {$[2.832,4.348]$} \\
\hline Lowest track & 1.268 & $(0.041)$ & {$[1.187,1.348]$} & 3.241 & $(0.302)$ & {$[2.649,3.834]$} \\
\hline Intermediate track & 1.337 & $(0.041)$ & {$[1.257,1.417]$} & 3.822 & $(0.314)$ & {$[3.205,4.438]$} \\
\hline Academic track & 0.870 & $(0.058)$ & {$[0.756,0.983]$} & 4.160 & $(0.443)$ & {$[3.292,5.028]$} \\
\hline \multicolumn{7}{|l|}{ Establishment size } \\
\hline $1-49$ & 1.318 & $(0.037)$ & {$[1.246,1.390]$} & 3.704 & (0.308) & {$[3.100,4.308]$} \\
\hline $50-249$ & 1.235 & $(0.045)$ & {$[1.146,1.323]$} & 3.682 & $(0.346)$ & {$[3.004,4.360]$} \\
\hline $250+$ & 1.088 & $(0.051)$ & {$[0.987,1.188]$} & 3.710 & (0.374) & {$[2.977,4.443]$} \\
\hline
\end{tabular}

AME refers to the average marginal effects on the survival rate in $\%$ from a $1 \%$ change in the apprenticeship wage in relation to low skilled workers wage $\left(W / W^{(l)}\right)$ and the natural logarithm of daily skilled worker wage $\left(\ln W^{(m)}\right)$, respectively. Estimates account for shared frailties in 35 occupation clusters. SE denotes occupation cluster robust standard errors. $\mathrm{N}=$ 41,921 observations, $n=94,223$ apprenticeships, $f=19,697$ incidences of non-completion. For estimated hazard ratios, see full results in Appendix: Table 9

The results suggest considerable heterogeneity. $W / W^{(l)}$ has a larger association with the survival rate in the apprenticeship period between 212 and 425 days; this time window covers the transition to the second year of the apprenticeship, which comes along with an increase in the apprenticeship wage. A possible explanation: apprentices reevaluate whether apprenticeship wages appropriately develop over time depending on the job content.

Furthermore, the effect on the survival rate is significantly lower for women. Female apprentices may have higher thresholds of apprenticeship wages or are more affected than men by correlated non-pecuniary factors when considering non-completion.

Moreover, the relationship between $W / W^{(l)}$ and the survival rate is lower for apprenticeships in larger establishments. Fewer profitable outside options, better perceived future employment possibilities, or other non-pecuniary benefits (like higher quality training programs and better support structures) may explain the lower association with the non-completion hazard.

The relationship between $W / W^{(l)}$ and the survival rate is also less pronounced for apprentices with an academic track diploma (so-called Abitur). As previously explained, graduates from the academic track may use the apprenticeship system to continue to the academic system. Thus, for these apprentices apprenticeship wages and skilled worker wages may be less important when considering non-completion, because they may strive for jobs and respective pecuniary and non-pecuniary benefits at the academic 
level. Selection presents another explanation, if apprentices from the academic track, for example, select into apprenticeships, which grant more non-pecuniary benefits and a better employment outlook. In this case, other benefits may be more important than the apprenticeship wage. ${ }^{27}$

Overall, the association of the apprenticeship wage and the non-completion hazard seems to depend on the apprentice's and establishment's characteristics; an increase in apprenticeship wages may not affect the non-completion hazard of each apprenticeship in the same way.

Concerning $\ln W^{(m)}$, the estimated AMEs do not significantly differ by sex, level of education, or establishment size at the $5 \%$ level. However, the association of the survival rate with $\ln W^{(m)}$ seems to be much stronger in the first 121 days of an apprenticeship; i.e, in the trial period. A likely explanation lies in the speed with which apprentices gather information on the job, especially in regards to the expected wages after completion and their perceived adequacy in light of other job characteristics. Stronger associations of wages after completion and the survival rate during the trial period suggest that most of this information is, in fact, gathered early on, while the legal requirements for ending an apprenticeship are lower in order to move on to more suitable and profitable jobs. Hence, this finding underlines the importance of apprenticeship non-completion in the occupational choice process of young people.

\section{Conclusion}

The number of German apprentices, who terminate their apprenticeship early, has been growing for years. Although the literature has acknowledged this development, there still are substantial blind spots in regards to the determinants of apprenticeship noncompletion. This paper closes a research gap by analyzing how non-completion is associated with apprenticeship wages and wage prospects after completion.

The paper identifies non-completion of apprenticeships in the SIAB data. Estimating piecewise exponential survival models with shared frailties by occupation, the results show a significant and robust negative association of both the apprenticeship wage and skilled worker wages with the non-completion hazard. The findings also suggest that apprenticeships, which pay $5 \%$ above average, have a 0.8 percentage points higher estimated survival rate on average. An apprenticeship leading to a skilled job that is paid $5 \%$ above average has an estimated survival rate that is 3.1 percentage points higher on

\footnotetext{
${ }^{27}$ It goes beyond the scope of this study to investigate the relationship between apprenticeship wage and non-completion of apprentices from the academic track in depth. However, it presents an interesting point for future research. One possibility to investigate the dependence on selection may be to separately analyze the association of apprenticeship wage and non-completion by typical and atypical occupations for academic track apprentices; i.e. those with very large shares of apprentices from the academic track. Kroll (2020, p. 134) shows that these are very distinct from typical occupations for apprentices from other high school tracks. I thank an anonymous reviewer for this suggestion. Another possibility to further investigate the importance of double qualifications may be to look at the typical training occupations of university entrants with VET degree. For the winter semester 2011, Scheller et al. (2013, pp. 40) document that university entrants with VET degree have been trained most commonly in banking and insurance occupations (25\%) but also in manufacturing occupations (21\%) - the latter being apprenticeships with typically lower shares of high schoo graduates from the academic track (cf. Kroll 2020).
} 
average. Especially in light of the proposed policy for a minimum apprenticeship wage, the results could indicate that such a policy may be ineffective without paying attention to developments of skilled worker wages in occupations and industries, which suffer from high rates of apprenticeship non-completion.

Given the limitations of this paper, however, the results do not allow for a causal interpretation. Although many important parameters of the selection process (occupation, industry, prior education, establishment size, and apprenticeship market tightness) are controlled for, the results still cannot be fully separated from the effect of the selection of apprentices that initially chose the occupation. Furthermore, all results have to be understood in context of other unobserved factors, which are correlated with the apprenticeship wage and wages after completion; for instance the quality of apprenticeships or the task profile of the respective job. The results show a differential association of the apprenticeship wage and the non-completion hazard depending on apprentice's sex and level of education and the size of the establishment. This indicates that wage policy is unlikely to affect all apprenticeships in the same manner. To shed light on the actual effectiveness of wage policies for the reduction of apprenticeship non-completion, further research is needed concerning the role of occupational sorting and the influence of non-pecuniary characteristics of apprenticeships.

Finally, the results indicate a stronger association of the wages after completion and the non-completion hazard in the first four month of an apprenticeship. This hints at the importance of how quickly apprentices gather information regarding future wages for non-completion and, thus, show that apprenticeship non-completion is a vital part of the occupational choice process of young people by directing them to more suitable (and more profitable) alternatives.

\section{Appendix}

See Tables 5, 6, 7, 8, and 9.

Table 5 Incidence rates in percent by time intervals

\begin{tabular}{lll}
\hline & Incidence rate & $95 \%-\mathrm{Cl}$ \\
\hline$(0-60]$ & 0.039 & {$[0.037,0.040]$} \\
$(60-121]$ & 0.058 & {$[0.056,0.060]$} \\
$(121-212]$ & 0.043 & {$[0.041,0.044]$} \\
$(212-425]$ & 0.027 & {$[0.027,0.029]$} \\
$(425-547]$ & 0.026 & {$[0.025,0.027]$} \\
$(547-1000]$ & 0.020 & {$[0.020,0.021]$} \\
\hline
\end{tabular}

Note: Incidences of non-completion per person-time, meaning the sum of duration in days of all observed apprenticeships in the interval 
Table 6 Estimation results for the Cox model and RI Logit model

\begin{tabular}{|c|c|c|c|c|c|c|}
\hline & \multirow{2}{*}{\multicolumn{2}{|c|}{$\frac{\text { Model of Table 3, }}{\text { column } 3}$}} & & & & \\
\hline & & & \multicolumn{2}{|l|}{ Cox } & \multicolumn{2}{|l|}{ RI Logit } \\
\hline & $\mathrm{HR}$ & SE & $H R$ & SE & Coef. & SE \\
\hline$W / W^{(l)}$ & $0.023 * * *$ & $(0.002)$ & $0.023 * * *$ & $(0.002)$ & $-5.189 * * *$ & $(0.088)$ \\
\hline $\ln W^{(m)}$ & $0.456 * * *$ & $(0.028)$ & $0.464 * * *$ & $(0.028)$ & $-1.923 * * *$ & $(0.083)$ \\
\hline Female & $0.864 * * *$ & $(0.023)$ & $0.875 * * *$ & $(0.116)$ & $-0.598 * * *$ & $(0.034)$ \\
\hline \multicolumn{7}{|l|}{ High school diploma } \\
\hline \multicolumn{7}{|l|}{ (ref:lowest track) } \\
\hline None & $0.907 * * *$ & $(0.027)$ & $0.906 * * *$ & $(0.023)$ & -0.052 & $(0.032)$ \\
\hline Intermediate track & $0.733 * * *$ & $(0.013)$ & $0.732 * * *$ & $(0.013)$ & $-0.365 * * *$ & $(0.022)$ \\
\hline Academic track & $0.590 * * *$ & $(0.016)$ & 0.588 & $(0.016)$ & $-0.651 * * *$ & $(0.033)$ \\
\hline Start. age & $2.023 * * *$ & $(0.116)$ & $2.026 * * *$ & $(0.116)$ & $0.817 * * *$ & $(0.071)$ \\
\hline Start. age sqr. & $0.984 * * *$ & $(0.001)$ & $0.984 * * *$ & $(0.002)$ & $-0.019 * * *$ & $(0.002)$ \\
\hline Start. year & $1.187 * * *$ & $(0.005)$ & $1.180 * * *$ & $(0.005)$ & $0.180 * * *$ & $(0.004)$ \\
\hline Foreign & $1.106 * * *$ & $(0.031)$ & $1.108 * * *$ & $(0.031)$ & $0.114 * *$ & $(0.037)$ \\
\hline \multicolumn{7}{|l|}{ Est. size } \\
\hline \multicolumn{7}{|l|}{ (ref: 1-49 employees) } \\
\hline $50-249$ & $0.859 * * *$ & $(0.005)$ & $0.857 * * *$ & $(0.018)$ & -0.012 & $(0.027)$ \\
\hline $250+$ & $0.798 * * *$ & $(0.023)$ & $0.796 * * *$ & $(0.023)$ & 0.070 & $(0.368)$ \\
\hline Est. age & $0.991 * * *$ & $(0.001)$ & $0.991 * * *$ & $(0.001)$ & $-0.009 * * *$ & $(0.001)$ \\
\hline East Germany & 0.975 & $(0.030)$ & 0.972 & $(0.030)$ & -0.029 & $(0.039)$ \\
\hline \multicolumn{7}{|l|}{ Industry } \\
\hline \multicolumn{7}{|l|}{ (ref:Retail/wholesale/gastronomy) } \\
\hline Farming/fishing/forestry & 1.039 & $(0.079)$ & 1.038 & $(0.079)$ & $-0.247 *$ & $(0.097)$ \\
\hline Earths/food/textiles & $0.719 * * *$ & $(0.028)$ & $0.721 * * *$ & $(0.028)$ & $-0.0475 * * *$ & $(0.050)$ \\
\hline Chemical/oil/metal & $0.581 * * *$ & $(0.023)$ & $0.586 * * *$ & $(0.023)$ & $-0.453 * * *$ & $(0.046)$ \\
\hline Electronics/vehicles/misc. prod. & $0.617 * * *$ & $(0.030)$ & $0.618 * * *$ & $(0.030)$ & $-0.360 * * *$ & $(0.055)$ \\
\hline Construction/water, energy supply & $0.815 * * *$ & $(0.032)$ & $0.813 * * *$ & $(0.032)$ & -0.071 & $(0.047)$ \\
\hline Logistics/Postal/Banking & 0.961 & $(0.043)$ & 0.957 & $(0.042)$ & $0.117 *$ & $(0.054)$ \\
\hline Public/private services & $0.843 * * *$ & $(0.028)$ & $0.845 * * *$ & $(0.028)$ & $-0.209 * * *$ & $(0.040)$ \\
\hline Health/education & $1.309 * * *$ & $(0.038)$ & $1.321 * * *$ & $(0.038)$ & $0.243 * * *$ & $(0.037)$ \\
\hline NGOs/culture/sports & $1.229 * * *$ & $(0.044)$ & $1.242 * * *$ & $(0.044)$ & 0.076 & $(0.048)$ \\
\hline SDR & 0.728 & $(0.123)$ & 0.806 & $(0.136)$ & $-1.407 * * *$ & $(0.217)$ \\
\hline MES & $1.286 * * *$ & $(0.058)$ & $1.269 * * *$ & $(0.057)$ & 0.091 & $(0.057)$ \\
\hline$u^{(l)} / u^{(m)}$ & $0.770 * * *$ & $(0.013)$ & $0.783 * * *$ & $(0.013)$ & $-0.621 * * *$ & $(0.019)$ \\
\hline$u^{(h)} / u^{(m)}$ & $1.438 * * *$ & $(0.087)$ & $1.389 * * *$ & $(0.084)$ & $1.605 * * *$ & $(0.079)$ \\
\hline Constant & $0.000 * * *$ & $(0.000)$ & & & $-359.088 * * *$ & $*(8.193)$ \\
\hline$\theta$ & & 0.115 & & 0.115 & & 0.266 \\
\hline LR-test & & 1,509 & & 1,510 & & 1,631 \\
\hline Log likelihood & & $-171,485$ & & $-213,676$ & & $-40,600$ \\
\hline Wald test & & 10,821 & & 8,419 & & 9,271 \\
\hline $\mathrm{AIC}$ & & 343,038 & & 427,405 & & 81,257 \\
\hline Observations & & 641,921 & & 255,403 & & 94,223 \\
\hline
\end{tabular}

$* * * \mathrm{p}<0.001, * * \mathrm{p}<0.01, * \mathrm{p}<0.05, \mathrm{n}=94,223$ apprenticeships, $\mathrm{f}=19,697$ non-completion. The table reports conditional hazard ratios (HR) of the fixed component for the Cox model and PWE model and coefficients (coeff.) for the RI logit model. Estimates are adjusted for shared frailties in 35 occupation clusters. SE denotes occupation cluster robust standard errors. The Cox model uses the Efron method for ties. The RI logit specification uses mean-variance adaptive GaussHermite quadrature as integration method. For the Cox model, a partial log likelihood is reported. $W / W^{(I)}$ refers to the apprenticeship wage in relation to low skilled workers wage, $\ln W^{(m)}$ to the natural logarithm of daily skilled worker wage, SDR to the supply-demand ratio of apprenticeships, MES to the marginal employment share of the establishment, $u$ to the number of unemployment days, and $\theta$ to the variance of the shared frailty 


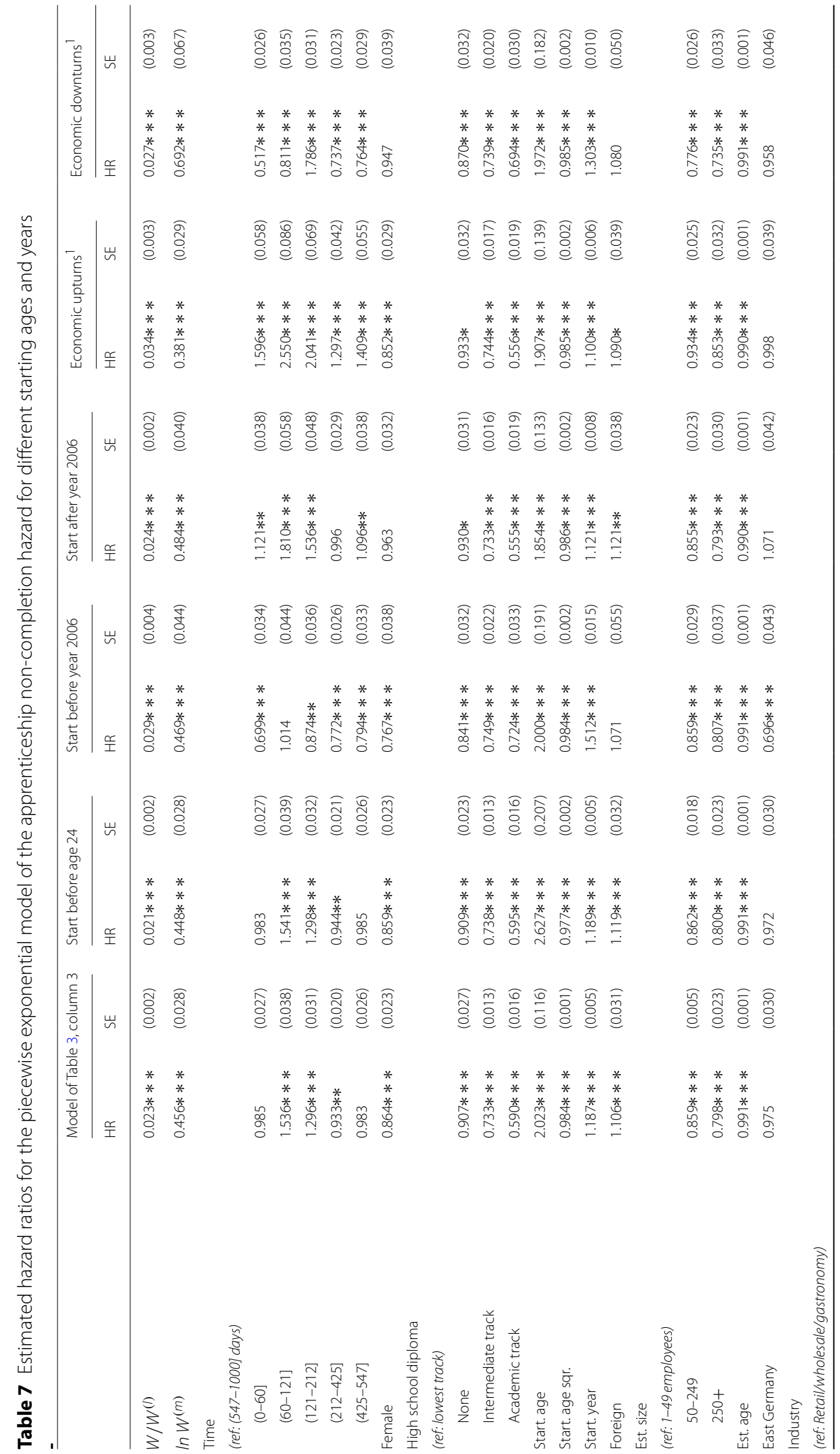




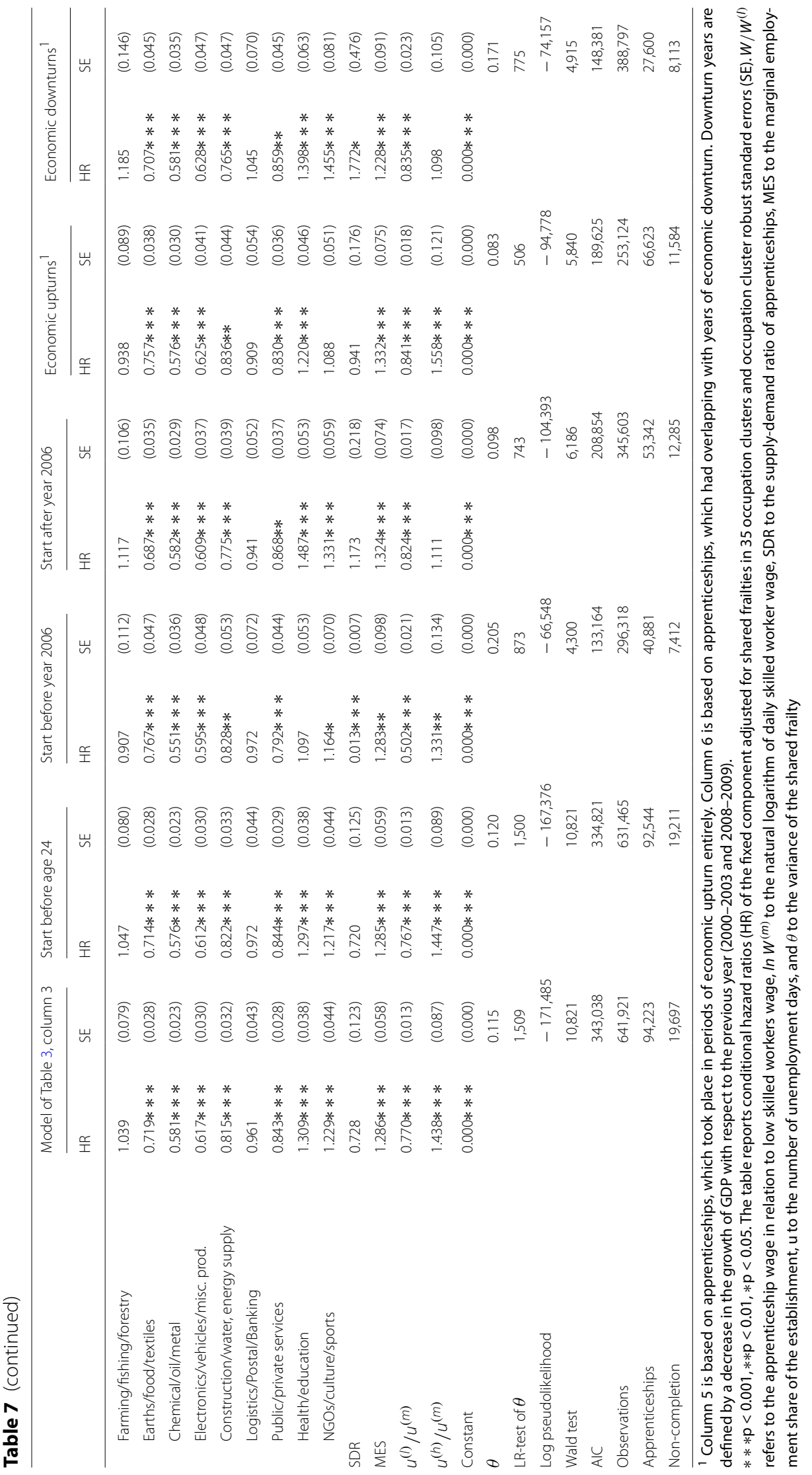


Table 8 Estimated hazard ratios for the piecewise exponential model of the apprenticeship noncompletion hazard for different censoring dates

\begin{tabular}{|c|c|c|c|c|c|c|}
\hline & \multicolumn{2}{|c|}{$\begin{array}{l}\text { Model of Table 3, } \\
\text { column } 3\end{array}$} & \multicolumn{2}{|c|}{$\begin{array}{l}\text { Censoring after } 914 \\
\text { days }\end{array}$} & \multicolumn{2}{|c|}{ Censoring after 730 days } \\
\hline & $H R$ & SE & $\mathrm{HR}$ & SE & $H R$ & SE \\
\hline$W / W^{(l)}$ & $0.023 * * *$ & $(0.002)$ & $0.022 * * *$ & $(0.002)$ & $0.016 * * *$ & $(0.001)$ \\
\hline $\ln W^{(m)}$ & $0.456 * * *$ & $(0.028)$ & $0.463 * * *$ & $(0.029)$ & $0.437 * * *$ & $(0.028)$ \\
\hline \multicolumn{7}{|l|}{ Time } \\
\hline \multicolumn{7}{|l|}{ (ref: (547-1000] days) } \\
\hline$(0-60]$ & 0.985 & $(0.027)$ & $0.931 *$ & $(0.026)$ & $0.865 * * *$ & $(0.027)$ \\
\hline$(60-121]$ & $1.536 * * *$ & $(0.038)$ & $1.451 * * *$ & $(0.036)$ & $1.351 * * *$ & $(0.038)$ \\
\hline$(121-212]$ & $1.296 * * *$ & $(0.031)$ & $1.222 * * *$ & $(0.030)$ & $1.148 * * *$ & $(0.031)$ \\
\hline$(212-425]$ & $0.933 * *$ & $(0.020)$ & $0.880 * * *$ & $(0.019)$ & $0.833 * * *$ & $(0.021)$ \\
\hline$(425-547]$ & 0.983 & $(0.026)$ & $0.928 * * *$ & $(0.025)$ & $0.885 * * *$ & $(0.026)$ \\
\hline Female & $0.864 * * *$ & $(0.023)$ & $0.871 * * *$ & $(0.023)$ & $0.865 * * *$ & $(0.024)$ \\
\hline \multicolumn{7}{|l|}{ High school diploma } \\
\hline \multicolumn{7}{|l|}{ (ref: lowest track) } \\
\hline None & $0.907 * * *$ & $(0.027)$ & $0.900 * * *$ & $(0.023)$ & $0.899 * * *$ & $(0.024)$ \\
\hline Intermediate track & $0.733 * * *$ & $(0.013)$ & $0.737 * * *$ & $(0.013)$ & $0.741 * * *$ & $(0.014)$ \\
\hline Academic track & $0.590 * * *$ & $(0.016)$ & $0.587 * * *$ & $(0.016)$ & $0.590 * * *$ & $(0.017)$ \\
\hline Start. age & $2.023 * * *$ & $(0.116)$ & $1.995 * * *$ & $(0.115)$ & $1.998 * * *$ & $(0.121)$ \\
\hline Start. age sqr. & $0.984 * * *$ & $(0.001)$ & $0.985 * * *$ & $(0.001)$ & $0.984 * * *$ & $(0.002)$ \\
\hline Start. year & $1.187 * * *$ & $(0.005)$ & $1.185 * * *$ & $(0.005)$ & $1.195 * * *$ & $(0.005)$ \\
\hline Foreign & $1.106 * * *$ & $(0.031)$ & $1.101 * *$ & $(0.032)$ & $1.113 * * *$ & $(0.033)$ \\
\hline \multicolumn{7}{|l|}{ Est. size } \\
\hline \multicolumn{7}{|l|}{ (ref: 1-49 employees) } \\
\hline $50-249$ & $0.859 * * *$ & $(0.005)$ & $0.861 * * *$ & $(0.018)$ & $0.858 * * *$ & $(0.019)$ \\
\hline $250+$ & $0.798 * * *$ & $(0.023)$ & $0.800 * * *$ & $(0.023)$ & $0.801 * * *$ & $(0.025)$ \\
\hline Est. age & $0.991 * * *$ & $(0.001)$ & $0.991 * * *$ & $(0.001)$ & $0.990 * * *$ & $(0.001)$ \\
\hline East Germany & 0.975 & $(0.030)$ & 0.980 & $(0.030)$ & 0.979 & $(0.032)$ \\
\hline \multicolumn{7}{|l|}{ Industry } \\
\hline \multicolumn{7}{|l|}{ (ref: Retail/wholesale/gastronomy) } \\
\hline Farming/fishing/forestry & 1.039 & $(0.079)$ & 1.032 & $(0.079)$ & 1.086 & $(0.086)$ \\
\hline Earths/food/textiles & $0.719 * * *$ & $(0.028)$ & $0.709 * * *$ & $(0.028)$ & $0.696 * * *$ & $(0.029)$ \\
\hline Chemical/oil/metal & $0.581 * * *$ & $(0.023)$ & $0.581 * * *$ & $(0.023)$ & $0.576 * * *$ & $(0.025)$ \\
\hline Electronics/vehicles/misc. prod. & $0.617 * * *$ & $(0.030)$ & $0.613 * * *$ & $(0.030)$ & $0.592 * * *$ & $(0.031)$ \\
\hline Construction/water, energy supply & $0.815 * * *$ & $(0.032)$ & $0.810 * * *$ & $(0.032)$ & $0.821 * * *$ & $(0.035)$ \\
\hline Logistics/Postal/Banking & 0.961 & $(0.043)$ & 0.959 & $(0.043)$ & $0.885 *$ & $(0.043)$ \\
\hline Public/private services & $0.843 * * *$ & $(0.028)$ & $0.849 * * *$ & $(0.029)$ & $0.859 * * *$ & $(0.031)$ \\
\hline Health/education & $1.309 * * *$ & $(0.038)$ & $1.301 * * *$ & $(0.038)$ & $1.256 * * *$ & $(0.038)$ \\
\hline NGOs/culture/sports & $1.229 * * *$ & $(0.044)$ & $1.226 * * *$ & $(0.044)$ & $1.198 * * *$ & $(0.045)$ \\
\hline SDR & 0.728 & $(0.123)$ & 0.779 & $(0.133)$ & $0.697 *$ & $(0.126)$ \\
\hline MES & $1.286 * * *$ & $(0.058)$ & $1.293 * * *$ & $(0.059)$ & $1.335 * * *$ & $(0.063)$ \\
\hline$u^{(l)} / u^{(m)}$ & $0.770 * * *$ & $(0.013)$ & $0.774 * * *$ & $(0.013)$ & $0.753 * * *$ & $(0.013)$ \\
\hline$u^{(h)} / u^{(m)}$ & $1.438 * * *$ & $(0.087)$ & $1.413 * * *$ & $(0.086)$ & $1.482 * * *$ & $(0.095)$ \\
\hline Constant & $0.000 * * *$ & $(0.000)$ & $0.000 * * *$ & $(0.000)$ & $0.000 * * *$ & $(0.000)$ \\
\hline$\theta$ & & 0.115 & & 0.117 & & 0.134 \\
\hline LR-test of $\theta$ & & 1,509 & & 1,493 & & 1,510 \\
\hline Log pseudolikelihood & & $-171,485$ & & $-168,037$ & & $-150,392$ \\
\hline Wald test & & 10,821 & & 10,276 & & 9,497 \\
\hline AIC & & 343,038 & & 336,142 & & 300,852 \\
\hline
\end{tabular}


Table 8 (continued)

\begin{tabular}{|c|c|c|c|c|c|c|}
\hline & \multicolumn{2}{|c|}{$\begin{array}{l}\text { Model of Table 3, } \\
\text { column } 3\end{array}$} & \multicolumn{2}{|c|}{$\begin{array}{l}\text { Censoring after } 914 \\
\text { days }\end{array}$} & \multicolumn{2}{|c|}{ Censoring after 730 days } \\
\hline & $\mathrm{HR}$ & SE & $\mathrm{HR}$ & SE & $H R$ & SE \\
\hline Observations & & 641,921 & & 641,122 & & 599,852 \\
\hline Apprenticeships & & 94,223 & & 94223 & & 94,223 \\
\hline Non-completion & & 19,697 & & 19,362 & & 17,495 \\
\hline
\end{tabular}

$* * * \mathrm{p}<0.001, * * \mathrm{p}<0.01, * \mathrm{p}<0.05$. The table reports conditional hazard ratios (HR) of the fixed component adjusted for shared frailties in 35 occupation clusters and occupation cluster robust standard errors (SE). $W / W^{(l)}$ refers to the apprenticeship wage in relation to low skilled workers wage, $\ln W^{(m)}$ to the natural logarithm of daily skilled worker wage, SDR to the supply-demand ratio of apprenticeships, MES to the marginal employment share of the establishment, $u$ to the number of unemployment days, and $\theta$ to the variance of the shared frailty

Table 9 Estimated hazard ratios for the piecewise exponential model of the apprenticeship noncompletion hazard accounting for interaction effects

\begin{tabular}{|c|c|c|}
\hline & $\mathrm{HR}$ & SE \\
\hline$W / W^{(l)}$ & $0.022 * * *$ & $(0.004)$ \\
\hline $\ln W^{(m)}$ & $0.618 * * *$ & $(0.059)$ \\
\hline \multicolumn{3}{|l|}{ Time } \\
\hline \multicolumn{3}{|l|}{ (ref: (547-1000] days) } \\
\hline$(0-60]$ & $144.807 * * *$ & $(57.156)$ \\
\hline$(60-121]$ & $27.609 * * *$ & $(9.923)$ \\
\hline$(121-212]$ & $2.289 *$ & $(0.841)$ \\
\hline$(212-425]$ & $7.326 * * *$ & $(2.419)$ \\
\hline$(425-547]$ & 1.142 & $(0.476)$ \\
\hline Female & $0.349 * * *$ & $(0.094)$ \\
\hline \multicolumn{3}{|l|}{ high school diploma } \\
\hline \multicolumn{3}{|l|}{ (ref: lowest track) } \\
\hline None & 1.340 & $(0.492)$ \\
\hline Intermediate track & 1.374 & $(0.364)$ \\
\hline Academic track & 0.983 & $(0.408)$ \\
\hline Start. age & $1.990 * * *$ & $(0.114)$ \\
\hline Start. age sqr. & $0.985 * * *$ & $(0.001)$ \\
\hline Start. year & $1.188 * * *$ & $(0.005)$ \\
\hline Foreign & $1.105 * * *$ & $(0.031)$ \\
\hline \multicolumn{3}{|l|}{ Est. size } \\
\hline \multicolumn{3}{|l|}{ (ref: 1-49 employees) } \\
\hline $50-249$ & 0.771 & $(0.236)$ \\
\hline $250+$ & 0.647 & $(0.222)$ \\
\hline Est. age & $0.991 * * *$ & $(0.001)$ \\
\hline East Germany & 0.965 & $(0.030)$ \\
\hline \multicolumn{3}{|l|}{ Industry } \\
\hline \multicolumn{3}{|l|}{ (ref:Retail/wholesale/gastronomy) } \\
\hline Farming/fishing/forestry & 1.036 & $(0.079)$ \\
\hline Earths/food/textiles & $0.710 * * *$ & $(0.028)$ \\
\hline Chemical/oil/metal & $0.581 * * *$ & $(0.023)$ \\
\hline Electronics/vehicles/misc. prod. & $0.620 * * *$ & $(0.030)$ \\
\hline Construction/water, energy supply & $0.803 * * *$ & $(0.032)$ \\
\hline Logistics/Postal/Banking & 0.966 & $(0.043)$ \\
\hline Public/private services & $0.838 * * *$ & $(0.029)$ \\
\hline Health/education & $1.295 * * *$ & $(0.038)$ \\
\hline NGOs/culture/sports & $1.219 * * *$ & $(0.044)$ \\
\hline
\end{tabular}


Table 9 (continued)

\begin{tabular}{lll}
\hline & $H R$ & SE \\
\hline SDR & $0.698 *$ & $(0.119)$ \\
MES & $1.291 * * *$ & $(0.058)$ \\
$u^{(l)} / u^{(m)}$ & $0.766 * * *$ & $(0.013)$ \\
$u^{(h)} / u^{(m)}$ & $1.430 * * *$ & $(0.087)$ \\
TimexW/W(l) & & \\
$($ ref: $(547-1000]$ days $)$ & & \\
$\quad(0-60]$ & $0.356 * * *$ & $(0.087)$ \\
$\quad(60-121]$ & 0.671 & $(0.143)$ \\
$\quad(121-212]$ & 0.820 & $(0.171)$ \\
$\quad(212-425]$ & $0.114 * * *$ & $(0.022)$ \\
$\quad(425-547]$ & $0.609 *$ & $(0.148)$ \\
FemalexW/W & $2.128 * * *$ & $(0.297)$
\end{tabular}

High school diplomax $W / W^{(l)}$

(ref: lowest track)

None
Intermediate track
Academic track

Est. sizexW/W(l)

(ref: 1-49 employees)

$$
\begin{aligned}
& \text { 50-249 } \\
& 250+
\end{aligned}
$$

Timex $\ln W^{(m)}$

(ref: (547-1000] days)

$$
\begin{aligned}
& (0-60] \\
& (60-121] \\
& (121-212] \\
& (212-425] \\
& (425-547]
\end{aligned}
$$

Femalex $\ln W^{(m)}$

High school diplomax $\ln W^{(m)}$

(ref: lowest track)

$$
\begin{aligned}
& \text { None } \\
& \text { Intermediate track } \\
& \text { Academic track }
\end{aligned}
$$

Est. sizex $\ln W^{(m)}$

(ref: 1-49 employees)

$$
\begin{aligned}
& \text { 50-249 } \\
& 250+
\end{aligned}
$$

Constant

\section{$\theta$}

LR-test of $\theta$

Log pseudolikelihood

Wald test

AIC
0.810

0.811

$3.345 * * *$

1.288

$2.010 * * *$

$0.332 * * *$

$0.525 * * *$

0.894

$0.721 * * *$

$(0.053)$

1.005

$(0.093)$

1.168*

0.923

(0.077)

0.875*

(0.052)

$0.810 *$

(0.074)

1.005

$(0.070)$

0.999

$0.000 * * *$

$(0.000)$

0.118

1536

- 171,247

11,449

342,607

$* * * \mathrm{p}<0.001, * * \mathrm{p}<0.01, * \mathrm{p}<0.05, \mathrm{~N}=641,921$ observations, $\mathrm{n}=94,223$ apprenticeships, $\mathrm{f}=19,697$ incidences of non-completion. The table reports conditional hazard ratios (HR) of the fixed component adjusted for shared frailties in 35 occupation clusters and occupation cluster robust standard errors (SE). $W / W^{(l)}$ refers to the apprenticeship wage in relation to low skilled workers wage, $\ln W^{(m)}$ to the natural logarithm of daily skilled worker wage, SDR to the supply-demand ratio of apprenticeships, MES to the marginal employment share of the establishment, $u$ to the number of unemployment days, and $\theta$ to the variance of the shared frailty 


\section{Acknowledgements}

The author wishes to thank Lutz Bellmann, Alexandra Uhly, Harald Pfeifer, and Verena Eberhard for helpful remarks on earlier versions of this paper. The author also thanks two anonymous reviewers for valuable suggestions improving the quality of the paper.

\section{Authors' contributions}

The author is the sole contributor to this study.

\section{Funding}

Not applicable.

\section{Availability of data and materials}

The data that support the findings of this study are available from the Institute for Employment Research (IAB) but restrictions apply to their public availability, which were used under license for the current study. Data are however available from the authors upon reasonable request and with permission of IAB and can only be accessed at IAB.

\section{Declarations}

\section{Competing interests}

The author declares that she has no competing interests.

Received: 8 June 2020 Accepted: 18 March 2021

Published online: 29 March 2021

\section{References}

Akerlof GA (1970) The market for "lemons": quality uncertainty and the market mechanism. Q J Econ 84(3):488-500. https://doi.org/10.2307/1879431

Antoni M, Ganzer A, vom Berge P (2016) Sample of integrated labour market biographies (SIAB) 1975-2014. IAB FDZDatenreport 04/2016

Arcidiacono P, Hotz VJ, Kang S (2012) Modeling college major choices using elicited measures of expectations and counterfactuals. J Econ 166(1):3-16. https://doi.org/10.1016/j.jeconom.2011.06.002

Arcidiacono P, Hotz VJ, Maurel A, Romano T (2020) Ex ante returns and occupational choice. J Political Econ 128(12):44754522. https://doi.org/10.1086/710559

Autor DH, Handel MJ (2013) Putting tasks to the test: human capital, job tasks, and wages. J Labor Econ 31 (S1, Part 2):S59-S96. https://doi.org/10.1086/669332

Becker G (1962) Investment in human capital: a theoretic analysis. J Political Econ 70(5, Part 2):9-49. https://doi.org/10. $1086 / 258724$

Beicht U, Walden G (2013) Duale Berufsausbildung ohne Abschluss - Ursachen und weiterer bildungsbiografischer Verlauf. Analyse auf Basis der BIBB-Übergangsstudie 2011. BIBB-Report 21/2013

Bellmann L, Gerner H-D, Leber U (2014) Firm-provided training during the Great Recession. Jahrb Natl Okon Stat 234(1):5-22. https://doi.org/10.1515/jbnst-2014-0103

Bellmann L, Stephani J (2012) Effects of double qualifications on various dimensions of job satisfaction. Empir Res Vocat Educ Train 4(2):95-114. https://doi.org/10.1007/BF03546511

Bessey D, Backes-Gellner U (2015) Staying within or leaving the apprenticeship system? Revisions of educational choices in apprenticeship training. Jahrb Natl Okon Stat 235(6):539-552. https://doi.org/10.1515/jbnst-2015-0603

Bohlinger S (2002) Einblick in eine vermeintliche Randerscheinung des deutschen Bildungssystems. Shaker Verlag, Aachen

Bol T, Weeden KA (2015) Occupational closure and wage inequality in Germany and the United Kingdom. Eur Sociol Rev 31(3):354-369. https://doi.org/10.1093/esr/jcu095

Bonin H, Fitzenberger B, Hillerich A (2016) Schule - Berufsausbildung - Arbeitsmarkt. Herausforderungen und Potenziale der ökonomischen Berufsbildungsforschung. Perspekt der Wirtschaftspolitik 17(3):208-231. https://doi.org/10.1515/ pwp-2016-0019

Christ A (2013) Betriebliche Determinanten vorzeitig gelöster Ausbildungsverträge. BWP 3(2013):4-5

Clark D (2011) Do recessions keep students in school? The impact of youth unemployment on enrolment in post-compulsory education in England. Economica 78:523-545. https://doi.org/10.1111/j.1468-0335.2009.00824.x

DGB (2019) Mindestausbildungsvergütung einführen, prekäre Beschäftigung eindämmen, den öffentlichen Dienst stärken! Press Release 28 from May 1st 2019. https://www.dgb.de/presse/++co++8874a1b2-6b53-11e9-9cec52540088cada. Accessed 22 July 2019

Fitzenberger B, Osikominu A, Völter R (2005) Imputation rules to improve the education variable in the IAB employment subsample. IAB FDZ-Methodenreport 03/2005

Gambin L, Hogarth T (2016) Factors affecting completion in apprenticeship training in England. J Educ Work 29(4):470493. https://doi.org/10.1080/13639080.2014.997679

Garloff A, Kuckulenz A (2006) Training, mobility, and wages: specific versus general human capital. Jahrb Natl Okon Stat 226(1):55-81. https://doi.org/10.1007/978-3-7908-1968-7_4

Gartner $\mathrm{H}$ (2005) The imputation of wages above the contribution limit with the German IAB employment sample. IAB FDZ-Methodenbericht 2/2005

Hirschi A (2011) Career-choice readiness in adolescence: developmental trajectories and individual differences. J Vocat Behav 79(2):340-348. https://doi.org/10.1016/j.jvb.2011.05.005 
Jaik K, Wolter SC (2019) From dreams to reality: market forces and changes from occupational intention to occupational choice. J Educ Work 32(4):320-334. https://doi.org/10.1080/13639080.2019.1637830

Jovanovic B (1979) Job matching and the theory of turnover. J Political Econ 87(5, Part 1):972-990. https://doi.org/10. $1086 / 260808$

Katz E, Ziderman A (1990) Investment in general training: the role of information and labour mobility. Econ J 100(403):1147-1158. https://doi.org/10.2307/2233964

Kotte V (2019a) Absolventen und Abbrecher - Zum Ausbildungsgeschehen im dualen System Mecklenburg-Vorpommerns. IAB-Regional 2/2019

Kotte V (2019b) Absolventen und Abbrecher - Zum Ausbildungsgeschehen im dualen System Schleswig-Holsteins. IAB-Regional 1/2019

Kroll S (2020) Vorbildung der Auszubildenden mit Neuabschluss. In: BIBB (ed.) Datenreport zum Berufsbildungsbericht 2020. Verlag Barbara Budrich, Leverkusen, pp 125-140

Kropp P, Danek S, Purz S, Dietrich I, Fritzsche B (2014) Die vorzeitige Lösung von Ausbildungsverträgen. Eine Beschreibung vorzeitiger Lösungen in Sachsen-Anhalt und eine Auswertung von Bestandsdaten der IHK HalleDessau. IAB-Forschungsbericht 13/2014

Kropp P, Schmillen A (2012) Mobilität in Deutschland. Wechsel konzentrieren sich auf wenige Berufe. IAB-Forum 2012:52-59. https://doi.org/10.3278/IFO1202W052

Lüthi S, Wolter SC (2020) Are apprenticeships business cycle proof? Swiss J Econ Stat 156(3):1-11. https://doi.org/10. 1186/s41937-019-0047-1

Mangan J, Trendle B (2008) Surviving apprenticeship training: a duration analysis of apprenticeship contracts in Australia. J Interdiscip Econ 19(4):379-398. https://doi.org/10.1177/02601079X08001900405

Mangan J, Trendle B (2017) Attrition and retention of apprentices: an exploration of event history data using a multi-state modelling framework. Educ Econ 25(4):406-417. https://doi.org/10.1080/09645292.2016.1213795

Mohr S, Troltsch K, Gerhards C (2015) Rückzug von Betrieben aus der beruflichen Ausbildung: Gründe und Muster. BIBBReport 4/2015

Mohrenweiser J, Backes-Gellner U (2010) Apprenticeship training: for investment or substitution? Int J Manpow 31(5):545-562. https://doi.org/10.1108/01437721011066353

Mortensen DT (1988) Wages, separations, and job tenure: on-the-job specific training or matching? J Labor Econ 6(4):445-471. https://doi.org/10.1086/298191

Mühlemann S, Ryan P, Wolter SC (2013) Monopsony power, pay structure, and training. Ind Labor Relat Rev 66(5):10971114. https://doi.org/10.1177/001979391306600504

Mühlemann S, Pfeifer H, Wittek B (2020) The effect of business cycle expectations on the German apprenticeship market: estimating the impact of Covid-19. Empir Res Vocat Educ Train 12(8):1-30. https://doi.org/10.1186/ s40461-020-00094-9

Mühlemann S, Wolter SC (2014) Return on investment of apprenticeship systems for enterprises: evidence from costbenefit analyses. IZA J Labor Policy. https://doi.org/10.1186/2193-9004-3-25

Mühlemann S, Wolter SC, Wüest A (2009) Apprenticeship training and the business cycle. Empir Res Vocat Educ Train 2:173-186

Protsch P (2014) Probleme auf dem Ausbildungsmarkt: Warum für Jugendliche mit Hauptschulabschluss der Einstieg so schwer ist. WZBrief Bildung 28:1-6

Rabe-Hesketh S, Skrondal A (2012) Multilevel and Longitudinal Modeling Using Stata, Third Edition. Volume II: categorical responses, counts, and survival. STATA Press

Rinawi M, Backes-Gellner U (2020) Firms' method of pay and the retention of apprentices. Oxf Econ Pap 72(1):269-291. https://doi.org/10.1093/oep/gpy074

Rohrbach-Schmidt D, Uhly A (2015) Determinanten vorzeitiger Lösungen von Ausbildungsverträgen und berufliche Segmentierung im dualen System. Eine Mehrebenenanalyse auf Basis der Berufsbildungsstatistik. Kolner Z Soz Sozpsychol 67(1):105-135. https://doi.org/10.1007/s11577-014-0297-y

Scheller P, Isleib S, Sommer D (2013) Studienanfängerinnen und Studienanfänger im Wintersemester 201112, Tabellenband. HIS: Forum Hochschule 6/2013, HIS, Hannover

Schmid E, Stalder BE (2012) Dropping out from apprenticeship training as an opportunity for change. In: Tynjälä P, Stenström M-L, Saarnivaara M (ed.) Transitions and transformations in learning and education, Springer, pp 117-130 https://doi.org/10.1007/978-94-007-2312-2_8

Schnitzler A (2020) Ergebnisse aus dem Nationalen Bildungspanel (NEPS): Vorzeitige Lösung von Ausbildungsverträgen: Gründe und Verläufe. In: BIBB (ed.) Datenreport zum Berufsbildungsbericht 2020. Verlag Barbara Budrich, Leverkusen, pp 211-214

Schönfeld G, Jansen A, Wenzelmann F, Pfeifer H (2016) Kosten und Nutzen der dualen Ausbildung aus Sicht der Betriebe. Bertelsmann Verlag, Bielefeld, Ergebnisse der fünften BIBB-Kosten-Nutzen-Erhebung. W

Schöngen K (2003) Ausbildungsvertrag gelöst = Ausbildung abgebrochen? Ergebnisse einer Befragung. BWP 5(2003):35-39

Schweri J, Hartog J (2017) Do wage expectations predict college enrollment? Evidence from healthcare. J Econ Behav Organ 141:135-150. https://doi.org/10.1016/j.jebo.2017.06.010

Stamm M (2012) Zur Rolle des Betriebs beim Ausbildungsabbruch. Zeitschrift für Berufs- und Wirtschaftspädagogik 108(1):18-27

Stevens M (1994) A theoretical model of on-the-job training with imperfect competition. Oxf Econ Pap 46(4):537-562. https://doi.org/10.1093/oxfordjournals.oep.a042147

Stinebrickner R, Stinebrickner T (2014) Academic performance and college dropout: using longitudinal expectations data to estimate a learning model. J Labor Econ 32(3):601-644. https://doi.org/10.1086/675308

Stinebrickner T, Stinebrickner R (2012) Learning about academic ability and the college dropout decision. J Labor Econ 30(4):707-748. https://doi.org/10.1086/666525 
Topel RH, Ward MP (1992) Job mobility and the careers of young men. Q J Econ 107(2):439-479. https://doi.org/10.2307/ 2118478

Tuor SN, Backes-Gellner U (2010) Risk-return trade-offs to different educational paths: vocational, academic and mixed. Int J Manpow 31(5):495-519. https://doi.org/10.1108/01437721011066335

Uhly A (2015) Vorzeitige Vertragslösungen und Ausbildungsverlauf in der dualen Berufsausbildung. Forschungsstand, Datenlage und Analysemöglichkeiten auf Basis der Berufsbildungsstatistik. BIBB Wissenschaftliche Diskussionspapiere, $\mathrm{p} 157$

Uhly A (2020) Alter der Auszubildenden und Ausbildungsbeteiligung der Jugendlichen im dualen System. In: BIBB (ed.) Datenreport zum Berufsbildungsbericht 2020. Verlag Barbara Budrich, Leverkusen, pp 162-171

Uhly A (2020) Vorzeitige Lösung von Ausbildungsverträgen. In: BIBB (ed.) Datenreport zum Berufsbildungsbericht 2020. Verlag Barbara Budrich, Leverkusen, pp 141-151

Wenzelmann F, Lemmermann H (2012) Betriebliche Kosten von Vertragslösungen. BWP 5(2012):4-5

Weßling K, Hartung A, Hillmert S (2015) Spatial structure counts: the relevance of regional labour-market conditions for educational transitions to vocational training. Empir Res Vocat Educ Train 7(12):1-20. https://doi.org/10.1186/ s40461-015-0024-6

Wiswall M, Zafar B (2015a) Determinants of college major choice: identification using an information experiment. Rev Econ Stud 82(2):791-824. https://doi.org/10.1093/restud/rdu044

Wiswall M, Zafar B (2015b) How do college students respond to public information about earnings? J Hum Cap 9(2):117-169. https://doi.org/10.1086/681542

Wolter SC, Ryan P (2011) Apprenticeship. In: Hanushek EA, Machin S, Woessmann, L (eds.) Handbook of the Economics of Education, vol 3. Elsevier B.V., North Holland, pp 521-576. https://doi.org/10.1016/B978-0-444-53429-3.00011-9 Wydra-Somaggio G (2017) Early termination of vocational training: dropout or stopout? IAB-Discussion Paper 3/2017

\section{Publisher's Note}

Springer Nature remains neutral with regard to jurisdictional claims in published maps and institutional affiliations.

\section{Submit your manuscript to a SpringerOpen ${ }^{\circ}$ journal and benefit from:}

- Convenient online submission

- Rigorous peer review

- Open access: articles freely available online

- High visibility within the field

- Retaining the copyright to your article

Submit your next manuscript at $\boldsymbol{\Delta}$ springeropen.com 